\title{
PUNITIVE DAMAGES UNDER FEDERAL STATUTES: A FUNCTIONAL ANALYSIS
}

Many federal statutes expressly provide or forbid punitive recoveries. ${ }^{1}$ Under others, however, the availability of punitive damages falls within the "penumbra of express statutory mandates." Courts are therefore sometimes faced with the necessity of making quasi-legislative decisions about whether to allow punitive awards. Express reliance on such usually ambiguous factors as the common law availability of the remedy, ${ }^{3}$ legislative history, ${ }^{4}$ or statutory language ${ }^{5}$ has produced, in the words of the Second Circuit, a "conflicting gaggle of general rules" about when punitive recoveries should be allowed. Recently, in Kozar v. Chesapeake \& Ohio Railway, ${ }^{7}$ a punitive award was upheld for the first time under the Federal Employers' Liability Act (FELA) ${ }^{8}$ in a

1. Some statutes specifically limit recoveries to losses suffered. See, e.g., Securities Exchange Act of $1934, \S 28,15$ U.S.C. $\S 78 \mathrm{bb}$ (a) (1970) [discussed in text accompanying notes $79-82$ infra]. Others specifically make greater recoveries available to claimants. See, e.g., 15 U.S.C. $\$ 15$ (1970) (treble damages allowed for violations of the antitrust laws); 35 U.S.C. $\$ 284$ (1970) (patent violations); 17 U.S.C. $\S 1$ (1970) (violations of copyriglit). Cf. United Mine Workers v. Pattou, 211 F.2d 742, 749 (4th Cir. 1954) ("Where Congress intended that damages in excess of the actual damage sustained by the plaintiff may be recovered in an action by statute, it lias found no difficulty in using language appropriate to that end").

2. Textile Workers Union v. Lincoln Mills, 353 U.S. 448, 457 (1957).

3. For example, in the first case in which the Supreme Court upheld an award of punitive damages, it said:

[T] $f$ repeated judicial decisions for more than a century are to be received as the best exposition of what the law is, the question [the availability of punitive damages] will not admit of argument.

Day v. Woodworth, 54 U.S. 362, 371 (1851); cf. Milwaukee \& St. P. Ry. v. Arms, 91 U.S. 489, 492 (1876) (pointing out that "[t]le doctrine is too well settled now to be shaken, that exemplary damages inay in certain cases be recovered").

4. On using legislative history, consider United States v. Klinger, 199 F.2d 645, 648 (2d Cir. 1952) (L. Hand, J.) ("When we ask what Congress 'intended,' usually there can be no answer, if what we mean is what any person or group of persons liad in mind").

5. On the difficulty of statutory construction, see Horack, Cooperative Action for Improved Statutory Interpretation, 3 VAND. L. REv, 382, 394 (1950):

For now, the most hopeful improvement in "statutory interpretation" seeins to be in a frank judicial recognition that in cases of real doubt the problems are not ones of interpretation but call for a limited exercise of the legislative function of the court. Judicial opmious drafted in these terms would be helpful to litigants and legislators, alike.

See generally, A Symposium on Statutory Construction, 3 VAND. L. Rev. 365 (1950).

6. Globus v. Law Research Serv., Inc., 418 F.2d 1276, 1284 (2d Cir. 1969).

7. 320 F. Supp. 335 (W.D. Mich. 1970).

8. 45 U.S.C. $\$ \$ 51-60$ (1970). FELA provides no measure of damages, stipulating only that the carrier shall be liable in damages to injured employees. Id. $\S 51$. 
decision that adds to the confusion about punitive recoveries under federal statutes. The Kozar court relied on a congressional intent to preserve the common law right to recover exemplary damages, but inadequately explaimed wly these factors had not previously justified a punitive award under the 60-year-old statute. It therefore appears that the court had some otlier reason for allowing the recovery.

This Comment suggests that the key to the existing confusion is that courts award punitive damages for different purposes under different statutes, whicli purposes can be described generally as conpensation, retribution, deterrence, or some conibination thereof. Part I criticizes the Kozar approacl to the problen and argues that that court in fact implicitly revealed the real rationale for the decision: FELA's purpose to promote safe working conditions. Part II examines the similarly unilluminating treatment nost courts lave given punitive claims under other federal statutes. Part III attempts to put order into the existing confusion by explaining the probable notivations behind varying judicial treatment of punitive claims under other federal statutes and analyzes Kozar's award in terms of the court's purpose. Finally, part IV advocates the explicit adoption of a functional analysis by the federal courts.

\section{I}

\section{The Kozar Approach}

John Kozar, foreman of a wrecking crew for the defendant railroad, was crushed to death when a nualfunctioning crane dropped a refrigerator car on him. His widow sued the railroad under both the wrongful death ${ }^{2}$ and survival ${ }^{10}$ provisions of FELA. Since punitive damages are prohibited in wrongful death actions, ${ }^{11}$ she appended a claim for punitive damages to the survival action, asserting that the railroad's repair department had repeatedly failed to respond to her husband's conplaimts about the crane's braking system. The railroad alleged that its repair records had been stolen, and that consequently there was no proof of a failure to repair. ${ }^{12}$ Mrs. Kozar nevertheless was able to show at trial that higher officials of the line were aware of the crane's

9. 45 U.S.C. $\$ 51(1970)$.

10. 45 U.S.C. $\$ 52(1970)$.

11. Punitive damages are traditionally not allowed in wrongful death actions because the purpose is a compensatory remedy for the losses to named beneficiaries. Mathies v. Kittrell, 350 P.2d 951, 953 (Okla. 1960); 1 T. Sedgwick, A Treatise on THE MeAsure OF DAMAges $\S 362$ (9th ed. 1913). This rule has been applied under FELA. E.g., Cain v. Southern Ry., 199 F. 211, 212 (C.C.E.D. Tenni. 1911).

12. The court seemed very doubtful about the claim that these records had been stolen, stressing that the "theft" had never been reported to the police. $320 \mathrm{~F}$. Supp. at 345 n.2, 
deficiencies and that the crane had been left in use even after the fatal accident. $^{13}$

The trial court instructed the jury that it could award punitive damages if it found the railroad guilty of "wilful, wanton or reckless disregard of the safety of John Kozar."14 The jury awarded nearly $\$ 120,000$ in compensatory damages on the wrongful death action, $\$ 500$ for John Kozar's fright and suffering under the survival action, and $\$ 70,000$ in punitive damages. ${ }^{15}$

Contending that punitive damages were not available under FELA, the defendant inoved for a new trial. The court denied the motion, although no federal court had ever upheld a punitive award under FELA since its passage in 1908. The court felt, first, that a common law action for punitive damages survived the passage of the Act because the Act was designed merely to remove certain common law obstacles to recovery and was not intended to constrict remedies. As an additional basis for the award, it postulated but did not rely on a statutory purpose to proinote railroad safety, suggesting that punitive awards would further this goal.

The Kozar rationale is not entirely without foundation. The legislative history shows that FELA's principal thrust was against courtcreated defenses that "[put] the entire burden of loss to life or limb upon the victim or the victim's family. . .."16 Thus, the Act eliminated the assuniption of risk doctrine ${ }^{17}$ and fellow servant rule, ${ }^{18}$ voided contractual releases froin liability, ${ }^{19}$ and reduced contributory negligence to mitigation of damages. ${ }^{20}$ There was no attempt to circumscribe previously existing common law remedies. ${ }^{21}$

13. Mrs. Kozar proved that management perso.ınel had witnessed previous failures of the crane, and produced a letter written by the defendant's car superintendent for its northern region to her husband discussing the crane's failings. $320 \mathrm{~F}$. Supp. at $343-45,359$.

14. 320 F. Snpp. at 341.

15. Id. at $340-41$.

16. This is a quotation from a speech by President Theodore Roosevelt, cited by the Senate Judiciary Committee in 1910. S. REP. No. 432, 61st Cong., 1st Sess. 4 (1910). To remedy this problem, the Act extended to railroad employees a cause of action for injuries caused by the carrier's negligence. 45 U.S.C. $\S 51$ (1970).

17. 45 U.S.C. $\S 54$ (1970).

18. 45 U.S.C. $\S 51$ extends protection to the cmployee for injuries caused by the negligence of the carrier or its employees or agents.

19. 45 U.S.C. $\$ 55$ (1970).

20. 45 U.S.C. $\$ 53$ (1970).

21. In 1910 the Senate Judiciary Committee stated that "[n]o purpose or intent on the part of Congress cau be found to limit or to take away from such an employee any right theretofore existing by which such einployees were entitled to a more extended remedy than that conferred upon them by the act." S. REP. No. 432, 61st Cong., 2d Sess. 12 (1910). The Kozar court quoted this language twice [320 F. Supp. at $347-48,350$ ] as demonstrating that the punitive damages remedy remained available 
However, some elements of FELA's legislative history indicate that Congress did not intend to authorize punitive recoveries. For example, under the 1906 Act, FELA's predecessor, contributory negligence was eliminated as a complete defense to a workman's action only when the eniployer was grossly negligent while the employee was only slightly negligent. $^{22}$ Only then did Congress think even compensatory awards were appropriate. In 1908, a minority of the Senate Judiciary Committee preferred restricting conıpensatory liability to extrahazardous tasks, ${ }^{23}$ again suggesting congressional misgivings about the general availability of compensatory damages. More importantly, although Congress twice expanded the Act by amendment ${ }^{24}$ and created a penal sanction under it, ${ }^{25}$ it never specifically offered punitive recoveries.

under FELA.

The court, seeking further support for its holding that remedies are not to be circumscribed, cited Moragne v. States Marine Lines, 398 U.S. 375 (1970). There plaintiff's husband was killed when the ship on which he was working sank in Florida territorial waters. Florida law did not provide a wrongful death recovery for seamen, and plaintiff was prevented from utilizing the Jones Act's wrongful death action [46 U.S.C. $\S 688$ (1970)] by the holding in The Harrisburg, 119 U.S. 199 (1886), that the scope of such federal legislation does not reach into state territorial waters. In Moragne the Court overruled Harrisburg, finding that the principle on which it was based was outdated even when it was established in this country, had been abandoned wholesale since that time by lower courts, and had stimulated much denunciation by Congress when the Jones Act was passed. The Court therefore removed the anomaly that a longshoreman could recover while a seaman could not, and allowed compensatory awards under the Act. Moragne does not provide mueh support for the holding in Kozar: In Kozar the original principle was not so clearly of judicial birth; there were no such clear congressional denunciations of the policy [see text accompanying notes 22-26 infra]; the court's holding does not bring it into line with subsequent practice [see text accompanying notes 33-43 infra]; continuing the existing practice does not perpetuate an anomaly; and the dimensions of the remedy do need to be clarified [see notes 207-08 infra].

22. Act of June 11, 1906, ch. 3073, $\$ 2,34$ Stat. 232. This Act was later found unconstitutional because it did not distinguish between interstate and intrastatc commerce and therefore exceeded Congress' powers. The Employers' Liability Cases, 207 U.S. 463, 498 (1908).

23. Rep. Parker, a dissenting member of the House Judiciary Committee, argued that imposition of liability for all negligence would violate due process as a class legislation against railroads. H.R. REP. No. 1386, 60th Cong., 1st Sess. 79 (1908). He added that "this bill very greatly enlarges the rights of the employee and imposes new and onerous burdens on the employer, making him practically an insurer." $1 d$. at 92.

24. In 1910 Congress amended the Act to make exphicit that actions existing in favor of deceased workers survived their deaths in favor of the named beneficiarics. Act of April 5, 1910, ch. 143, \& 2, 36 Stat. 291, codified at 45 U.S.C. $\$ 59$ (1970). In 1939 Congress clarified its repudiation of assumption of risk. Act of Aug. 11, 1939, ch. 685 , § 1, 53 Stat. 1404, amending 45 U.S.C. $\$ 54$ (1970).

25. Any person who attempts to imterfere with the effort of an injured employee to utilize the Acts provisions shall be liable to a fine of not more than $\$ 1,000$ or imprisonment for not more than one year, or both. Act of Aug. 11, 1939, ch. 685, $\S 3$, 53 Stat. 1404, codified at 45 U.S.C. $\S 60$ (1970). This provision has been interpreted by one court. In Greenwood v. Atcheson, T. \& S.F. Ry., 129 F. Supp. 105, 107-08 (S.D. Cal. 1955), plaintiff alleged that he had been fired for sumg under 
Two commentators simply took it for granted that the remedy was not available under FELA. ${ }^{20}$

Furthermore, the pre-1908 cases upon which Kozar relied heavily would not have allowed exemplary awards unless the defendant "has acted wantonly, or oppressively or with such malice as implies a spirit of mischief or crimmal indifference to civil obligations," standard than that adopted in Kozar. ${ }^{28}$ Federal courts at that time allowed punitive recoveries against railroads only in egregious cases, such as false arrest of a passenger, ${ }^{29}$ or wrongful ejection of a passenger froin a (sometimes moving) train. ${ }^{30}$ In fact, only two pumitive damages cases involving nonwillful misconduct came to the Supreme Court during this period, and in both the awards were reversed. ${ }^{31}$ The weakness of relying on pre-1908 cases is furtler underscored by the infrequency of reported cases considering punitive recoveries under FELA, ${ }^{32}$ which may imdicate that litigants thought hitle of their chances for recovery.

FELA; the court dismissed, holding that section 60 created only a criminal and not a private cause of action, and that firing an employee for suing was not an "order, rule, contract, regulation, or device" as prohibited by the statute.

26. 2 M. Roberts, Federal Liabilities of Carriers $\$ 621$ (1918); C. MCCORMICK, HaNdBOOK ON THE LAW OF DaMaGes $\$ 81$, at 287 (1935).

27. Lake Shore \& M.S. Ry. v. Prentice, 147 U.S. 101, 107 (1893). The Court had on other occasions suggested equally stringent standards for punitive awards. See, e.g., Scott v. Donald, 165 U.S. 58, 86 (1897) (punitive damages allowed "where a tort is aggravated by evil motive, actual malice, deliberate violence, or oppression"); Barry v. Edınunds, 116 U.S. 550, 562-65 (1886) (punitive damages as punishment for lawless conduct).

28. The cases in which the Court did allow punitive awards to stand involved conduct very different froin that charged against the railroad in Kozar. In the first case, Day v. Woodworth, 54 U.S. 362 (1851), the defendant had entered plaintiff's land and cut down his dam. In Barry v. Edmunds, 116 U.S. 550 (1886), a pumitive award was upleld against a defendant guilty of abuse of process.

29. Lake Shore \& M.S. Ry. v. Prentice, 147 U.S. 101 (1893).

30. See, e.g., Fell v. Nortliern Pac. Ry., 44 F. 248 (C.C.N. Dak. 1890); Gallena v. Hot Springs R.R., 13 F. 116 (C.C.E.D. Ark. 1882); Brown v. Memphis \& C.R.R., 7 F. 51 (C.C.W.D. Tenn. 1881).

31. Milwaukee \& St. P. Ry. v. Arms, 91 U.S. 489 (1875) (plaintiff injured in collision of two trains sought punitive damages for gross negligence); Philadelphia, W. \& B. Ry. v. Quigley, 62 U.S. 202 (1858) (plaintiff sought punitive damages agamst railroad for unwitting hibe1). The Kozar court seized upon language in the Arms opinion indicating that recovery for nonwillful conduct would be allowed where the defendant displayed "that reckless indifference to the rights of others which is equivalent to an intentional violation of thein" [91 U.S. at 493], but this reliance is unjustified. Not only did the Court reverse the punitive award in Arms, inaking the quoted language dictum, bnt it also stressed that allowing punitive damages was "a great departure froun the principle on which damages in civil suits are awarded" [Id. at 492], and that the malice required to support an award inust imply "that the wrong coinplained of was conceived in the spirit of mischief, or criminal indifference to civil obligations." Id. at 493. Thus, Arms cannot be regarded as authority for the test Kozar einploys.

32. The Kozar court was able to find only six arguably dealing with the question. See note 34 infra. 
Therefore, the Kozar court's reliance on a preserved common law right of recovery is unconvincing.

A second important defect in the court's approach is its reliance on a dictuin of United States Steel Corp. v. Fuhrman, ${ }^{33}$ the only case that the court felt stood as authority for allowing punitive damages under FELA. $^{34}$ Fuhrman involved a $\$ 16$ million punitive award against the owner of a freighter for the deaths of 10 crewmen who drowned as a result of the captain's extrenie recklessness. The district court upheld the award on two bases: First, the traditional availability of punitive damages in admiralty; ${ }^{35}$ and second, the riglits it felt were implicit in FELA. ${ }^{36}$ The first basis was, of course, inapplicable in Kozar, ${ }^{37}$ and the second was supported only by Ennis v. Yazoo \& Missouri Valley Railway, ${ }^{38}$ an unsupported Mississippi state court decision possibly premised on state comnion law rather than on FELA. Therefore, although Kozar rejects Ennis as autlority, ${ }^{30}$ it indirectly relies on it through Fuhrman.

United States Steel appealed in Fuhrman, and the Sixth Circuit reversed for lack of proof that the corporation had ratified the wrongful acts of the captain. ${ }^{40}$ In a dictum the court suggested that punitive damages might be recoverable against the owner of a vessel in some

33. 407 F.2d 1143 (6th Cir. 1969), cert. denied, 398 U.S. 958 (1970). This action was brought under the Jones Act, 46 U.S.C. $\$ 688$ (1970), which applies to seamen the protections that FELA applies to railroad employees. See Note, Punitive Damages in Admiralty, 18 HASTINGS L.J. 995 (1967).

34. Kozar concluded that "only Fuhrman seems to stand as authority." $320 \mathrm{~F}$. Supp. at 350. Other cases discussed were Missouri-K.-T. Ry. v. Ridgway, 191 F.2d 363 (8th Cir. 1951) (remanding for a new trial because the plaintiff's lawyers made improper appeals to the jury's prejudice; the court felt the unusually large award was based on a punitive, rather than a compensatory, rationale and was therefore prohibited under the Act); Cain v. Southern Ry., 199 F. 211 (C.C.E.D. Tenn. 1911) (denying the widow of a railroad worker punitive damages because the 1908 version of FELA did not provide for survival of actions. This anomaly was corrected by Congress in 1910. See note 24 supra); Gunnip v. Warner Co., 43 F.R.D. 365 (E.D. Pa. 1968) (allowing amendment to a complaint under the Joncs Act to add a claim for punitive damages because such a recovery was not unquestionably beyond the scope of the Act, citing the district court opinion in Fuhrman); Hclsel v. Pennsylvania R.R., 84 F. Supp. 296 (E.D.N.Y. 1949) (reducing a compensatory award under FELA because it seemed too large); Ennis v. Yazoo \& M.V. Ry., 118 Miss. 509, 79 So. 73 (1918) (allowing pumitive damages to the mother of a deceased railroad worker, but probably on the basis of Mississippi common law rather than FELA).

35. Petition of Den Norske Amerikanlinje, 276 F. Supp. 163, 172 (N.D. Ohio 1967). The damages figure is in Kozar, 320 F. Supp. at 351.

36. 276 F. Supp. at 174-75.

37. It was cited as a distinguishing feature by the defendant in Kozar. 320 F. Supp. at 351 .

38. 118 Miss. 509, 79 So. 73 (1918) [discussed in note 34 supra].

39. Kozar pointed out that "[t]he opinion cites no authority for its holding and it is unclear whether that court relied upon the Federal Employers' Liability Act, or the state common law." 320 F. Supp. at 351.

40. 407 F.2d 1143, 1146-48 (1969). 
cases, ${ }^{41}$ but since this dictum may have been based either on the peculiarities of admiralty or on rights created by statute, it may not be authority for the Kozar holding at all.42 It certainly is not adequate support for Kozar's finding that "in this circuit, punitive damages are recoverable in an action under the Federal Employers' Liability Act."43

A much better ground for the award was suggested in the Kozar court's conclusion: The court sought "to deter severe violations of common law and statutory duties" 44 in order to uphold the purpose of FELA, which is "to promote safe operating conditions." 45 Congressional concern with safety under FELA can be inferred front the earlier enactment of the Safety Appliance Act (SAA), ${ }^{46}$ which was aimed at reducing the dangers of rail travel and work, and from the Senate Judiciary Committee's citation of the continuing liazards of such work to justify passage of FELA. ${ }^{47}$ More recently, 1957 amendinents imcreasing the statutory penalty for violations of SAA indicate that Congress continues to be concerned with reducing these dangers. ${ }^{48}$ Since FELA itself was intended to place the burden of mjuries on those who "measurably control their causes,"

41. The court stated: "We think the better rule is that punitive damages are not recoverable against the owner of a vessel for the act of the master unless it can be shown that the owner authorized or ratified the acts of the master. . . "Id. at 1148 .

42. The Fuhrman court stressed the unique problems of the maritime industry, where the complete deference owed by sailors to their captain may raise special duties that should be regulated by the possibility of punitive awards. This lends additional weight to the Kozar defendant's argunent that any authorization of punitive awards in Fuhrman was restricted to adiniralty. See note 37 supra.

43. 320 F. Supp. at 351.

44. 320 F. Supp. at 357. Cf. Brown v. Memphis \& C.R.R., 7 F. 51, 63 (C.C.W.D. Tenn. 1881) (punitive damages against railroads a "method of enforcing upon the corporation obedience to the duties [to passengers] required of it as a common carrier").

45. 320 F. Supp. at 387.

46. 45 U.S.C. $\S \S 1-46$ (1970). The Act provides for certain minimal safety features, such as grab irons [id. § 4] and automatic couplers [id. § 2], which are required on all cars used in interstate commerce. Its title when passed was "An Act to Promote the Safety of Employees and Travelers," Act of March 2, 1893, 27 Stat. 231.

47. Reporting on amendments to the Act, the Committee stressed that "[t]he tremendous loss of life and linb on the railroads of this country is appalling. The total casualties to train men on the interstate railroads of the United States for the year 1908 was 281,645." S. ReP. No. 432, 61st Cong., 2d Sess. 2 (1910), quoted in Kozar v. Chesapeake \& O. Ry., 320 F. Supp. 335, 346 (W.D. Mich. 1970).

48. The United States Attorney inust seek the statutory penalty in federal court when a verified information is filed with him. 45 U.S.C. $\$ \S 6,13(1970)$. In 1957 Congress increased the penalty from 100 dollars to 250 dollars. 45 U.S.C. $\S \S 6,13$ (1970) (originally enacted as Act of Aug. 14, 1957, Pub. L. No. 85-135, $\S 1,71$ Stat. 352).

49. St. Louis, I.M. \& S. Ry. v. Taylor, 210 U.S. 281 (1908) (referring to the requirentents of the SAA), quoted in S. ReP. No. 432, 61st Cong., 2d Sess. 2 (1910) (report of the Senate Judiciary Committee on 1910 amendnents to FELA); also quoted in Kozar, 320 F. Supp. at 346. 
the same strict rules for the safety of his employees as he does for the safety of passengers and strangers," ${ }^{50}$ providimg remedies that prompt greater safety consciousness serves the goals of the Act. The deterrent justification hinted at by the Kozar court is therefore the most legitimate ground for the decision.

\section{II}

\section{Punitive Damages Under Federal Statutes}

Other federal statutes are also unclear about whether they authorize punitive damages, and courts have differed about the availability of the remedy under some of them. These decisions seem confused and are difficult to reconcile under the ordinary criteria upon which they expressly rely. This part reviews some of these decisions and their varying rationales.

\section{A. Labor Statutes}

Punitive damages have been sought under two separate federal schemes of labor legislation: the Labor Management Relations Act (LMRA $)^{51}$ and the Labor Management Reporting and Disclosure Act (LMRDA). ${ }^{52}$ LMRA is the present version of the National Labor Relations Act of $1935,{ }^{53}$ as amended by the Taft-Hartley Act in 1947. ${ }^{54}$ That Act was designed to promote industrial peace by stressing rehance on collective bargaining and by regnlating the use of economic weapons by parties to labor disputes. ${ }^{65}$ Thus, both parties are required to bargain in good faith, ${ }^{56}$ to give advance notice of their desire to alter the terms of a collective bargaming agreement, ${ }^{67}$ and to bargain before changing the terms of an existing agreement. ${ }^{58}$

50. H.R. REP. No. 1386, 60th Cong., 1st Sess. 3 (1908).

51. 29 U.S.C. $\$ \S 141-87$ (1970). See Comment, Monetary Recovery Under the Federal Labor Statutes, 45 Texas L. Rev. 881 (1967); Note, Compensatory and Punitive Damages Under L.M.R.A. Sections 301 and 303, 47 CORNELL L.Q. 112 (1961).

52. 29 U.S.C. $\$ \S 401-531$ (1970).

53. Act of July $5,1935,49$ Stat. 452.

54. Act of June 23, 1947, 61 Stat. 136.

55. In passing the Taft-Hartley Act in 1947, Congress declared its purpose and policy as follows:

It is the purpose and policy of this chapter, in order to promote the full flow of commerce, to prescribe the legitimate rights of both employees and employers in their relations affecting commerce, to provide orderly and peaceful procedures for preventing the interference by either with the legitimate rights of the other ... to define and proscribe practices on the part of labor and management which affect commerce and are inimical to the general welfare, and to protect the rights of the public in connection with labor disputes affecting commerce.

29 U.S.C. $\$ 141$ (b) (1970).

56. 29 U.S.C. $\$ 158(d)(1970)$.

57. Id.

58. Id. See also NLRB v. Katz, 369 U.S. 736, 742-43 (1962). 
The amended Act also created remedies in federal court for breaches of collective bargaining agreements. Section $303^{59}$ gives anyone mjured by a labor organization's unfair labor practices an action to recover "the damages by him sustamed," and the Supreme Court has held that this language precludes punitive awards. ${ }^{60}$ On the other hand, section $301^{61}$ actions for breach of collective bargaining agreements are not subject to a similar express limitation. Two courts have been faced with punitive claims under this section, but have reached conflicting results. The Third Circuit denied the claim because "[i]t is the general policy of the federal labor laws . . . to supply remedies rather than punisliments."02 Subsequently, in Sidney Wanzer \& Sons, Inc. v. Milk Drivers' Local $753,^{63}$ a district court upheld a punitive award in hopes of affecting the future bargaining labits of the parties. It distinguished the Third Circuit decision on the basis that the bargaining relationship there had ceased, so that a punitive award could not influence the future relations of the parties. ${ }^{64}$

LMRDA was passed for a different reason: to protect union members from labor racketeering. ${ }^{65}$ It attempts to regulate internal union affairs by giving all union members a bill of rights ${ }^{66}$ enforceable against union leadership through civil actions in federal courts for "such relief ... as may be appropriate." bility of punitive damages. One has held that appropriate relief does not include punitive damages under LMRDA because Congress had manifested in LMRA an intention not to make punitive awards available. ${ }^{88}$ Other courts have implied that punitive recoveries are available

59. 29 U.S.C. $\$ 187$ (1970).

60. Teamsters Local 20 v. Morton, 377 U.S. 252 (1964); accord, United Mine Workers v. Patton, 211 F.2d 742 (4th Cir. 1954).

61. 29 U.S.C. $\$ 185$ (1970).

62. United Shoe Workers Local 127 v. Brooks Shoe Mfg. Co., 298 F.2d 277, 284 (3rd Cir. 1962) (Biggs, C.J.). In this case the employer, in breach of an express term in his collective bargaining contract, moved his shop to another town. The award could only have had pumitive purposes.

63. 249 F. Supp. 664 (N.D. IIl. 1966).

64. Id. at $669-70$.

65. The statute begins with a statement of findings:

The Congress further finds, from recent investigation in the labor and management fields, that there have been a number of instances of breach of trust, disregard of the rights of individual employees and other failures to observe high standards of responsibility and ethical conduct. . . .

29 U.S.C. \& 401(b) (1970). See also Gartner v. Soloner, 384 F.2d 348, 355 (3rd Cir. 1967); Cole v. Hall, 35 F.R.D. 4, 8 (E.D.N.Y. 1964).

66. 29 U.S.C. $\$ 411$ (1970).

67. 29 U.S.C. $\$ 412(1970)$.

68. Burris v. International Bhd. of Teamsters, 224 F. Supp. 277, 280-81 (W.D. N.Car. 1963); relied upon in Magelssen v. Operative Plasterers Local 518, 240 F. Supp. 259, 263 (W.D. Mo. 1965). 
where the defendant is guilty of "willful malice." The Fifth Circuit has allowed them because they "[serve] as a deterrent to those abuses which Congress sought to prevent."70 Although unwilling to award punitive damages, some courts have broken with precedent ${ }^{71}$ and made awards for hitigation costs, ${ }^{72}$ generally on the ground that added incentive to sue aids in the fight against labor racketeering. ${ }^{73}$

\section{B. Securities Acts of $1933 \& 1934$}

While Congress, partly in response to the 1929 stock market crash, ${ }^{74}$ prohibited certain deceptive practices and provided victims with actions for damages, ${ }^{75}$ the courts have greatly expanded the remedies available under the Acts by implying private causes of action for violation of statutory prohibitions. The Supreme Court upheld imphication of private remedies because "the possibility of civil damages . . . serves as a most effective weapon in the enforcement of the [Act],"7B and that therefore they should be allowed because "it is the duty of the courts . . . to provide such remedies as are necessary to make effective the congressional purpose." 77 The Court has not dealt specifically with the question of punitive damages under the Acts, however.

In spite of the Supreme Court's strong general language, lower courts have not often allowed punitive recoveries against violators. ${ }^{78}$

69. Vars v. International Bhd. of Boilermakers, 215 F. Supp. 943, 952 (D. Conn. 1963); cf. Magelssen v. Operative Plasterers Local 518, 240 F. Supp. 259, 263 (W.D. Mo. 1965); Cole v. Hall, 35 F.R.D. 4, 7 (E.D.N.Y. 1964) (referring to a requirement of the New York common law claim).

70. International Bhd. of Boilermakers v. Braswell, 388 F.2d 193, 200 (5th Cir. 1968); cf. Farowitz v. Associated Musicians Local 802, 241 F. Supp. 895 (S.D. N.Y. 1965) (awarding one dollar compensatory and $\$ 1,000$ pumitive damages to a union member expelled for circulating a mimeoed attack on the policy of his local).

71. See Magellssen v. Operative Plasterers Local 518, 240 F. Supp. 259, 263 (W.D. Mo. 1965); McGraw v. United Ass'n of Journeymen \& Apprentices of Plumbing, 216 F. Supp. 655, 664 (E.D. Tenn. 1963); Vars v. International Bhd. of Boilermakers, 215 F. Supp. 942, 952 (D. Conn. 1963).

72. E.g., Gartner v. Soloner, 384 F.2d 348 (3rd Cir. 1967) (counsel fees); International Bhd. of Boilermakers v. Rafferty, 348 F.2d 307 (9th Cir. 1965) (expenses of appeal within union).

73. Gartner v. Soloner, 384 F.2d 348, 355 (3rd Cir. 1967) (stressing "assistance to a single umionist fighting his lonely battle for justice").

74. See generally Hanna \& Turlington, Protection of the Public Under the Securities Exchange Act, 21 VA. L. REV. 251 (1935).

75. Securities Act of 1933, 15 U.S.C. \$\$ 77a-77bbbb (1970); Securities Exchange Act of 1934, 15 U.S.C. $\$ \$ 78 \mathrm{a}-78 \mathrm{jj}(1970)$.

76. J.I. Case Co. v. Borak, 377 U.S. 426, 432 (1964).

77. Id. at 433.

78. See Comment, Punitive Damages in Implied Private Actions for Fraud Under the Securities Laws, 55 CORNELl L. REv. 646, 648-51 (1970). 
Partly this is the result of section $28(a)^{79}$ of the 1934 Act, which seemingly precludes punitive awards under its provisions. Some courts have, however, allowed them in implied actions under section $10(b)^{80}$ on the theory that actions created by judicial fiat are not covered by the statute's express limitations, and that therefore the common law right to punitive recoveries should control. ${ }^{81}$ This view has been rejected by most courts. ${ }^{82}$

Under section $17 \mathrm{a}^{83}$ of the 1933 Act there is no similar prohibition. ${ }^{84}$ Nevertheless, in Globus v. Law Research Service, Inc., ${ }^{85}$ the Second Circuit rejected using punitive damages for section 17 a violations. While conceding that exemplary damages would deter violations, ${ }^{80}$ the court reasoned that since the expressly created causes of action were linited to compensatory recoveries, to allow punitive damages in implied causes of action would "jolt and startle the draftsmen." ${ }^{87}$ Furthermore, the Act could be effectively enforced without punitive damages because numnerous alternative sanctions for wrongful behavior exist. ${ }^{88}$ The court also worried about the possibility of bankrupting violators already burdened with heavy compensatory damages. ${ }^{89}$

\section{Civil Rights Acts}

The Civil Rights Acts were designed to give freedmen legal weap-

79. 15 U.S.C. $\$ 78 b b(a)(1970)$ :

[N]o person permitted to maintain a suit for damages under the provisions of this chapter shall recover, through satisfaction of judgment in one or more actions, a total amount in excess of his actual damages on account of the act complained of.

80. 15 U.S.C. $\$ 78 \mathrm{j}(\mathrm{b})(1970)$.

81. deHaas v. Empire Petroleum Co., 302 F. Supp. 647, 649 (D. Colo. 1969); cf. Hecht v. Harris, Upham \& Co., 283 F. Supp. 417, 444-45 (N.D. Cal. 1968).

82. Baumel v. Rosen, 412 F.2d 571, 576 (4th Cir. 1969), cert. denied, 396 U.S. 1037 (1970); Green v. Wolf Corp., 406 F.2d 291, $302-03$ (2d Cir. 1968), cert. denied, 395 U.S. 977 (1969).

83. 15 U.S.C. $\& 77 \mathrm{q}(a)(1970)$, which makes unlawful any use of interstate commerce to defraud or mislead a purchaser in the offer of securities for purchase. A private right of action has been implied under this section as under section $10 \mathrm{~b}$ of the 1934 Act. On implication of remedies, see generally Note, Implying Civil Remedies From Federal Regulatory Statutes, 77 HARv. L. REv. 285 (1963).

84. Sections 10 and 11 of the Act, 15 U.S.C. $\$ \S 77 \mathrm{k}, 771$ (1970), which specifically give plaintiffs causes of action for damages, himit these recoveries to the actual loss, but there is no blanket provision for the whole Act. Some courts have acted on analogy to these two sections when dealing with section $17 \mathrm{a}$, but simce there is a lower standard of proof to recover under them, it is reasonable to disregard their limitation to actual damages when dealing with 17 a claims.

85. 418 F.2d 1276 (2d Cir. 1969).

86. Id. at 1284 .

87. Id.

88. The court noted that alternative sanctions included a fine, five years in prison, suspension from the Securities and Exchange Commission, and high compensatory recoveries with class actions under FED. R. Crv. P. 23(a), 418 F.2d at 1285.

89. Id. 
ons with which to protect their new rights. ${ }^{00}$ Section 1 of the Act of $1871^{91}$ makes those who violate another's civil rights "liable to the party injured in an action at law, suit in equity, or other proper proceeding." The courts at first constricted the scope of the Act, ${ }^{92}$ and compensatory recoveries gained general acceptance only in this century. ${ }^{93}$

Punitive recoveries lave gained acceptance as well, although the reasoning behind their availability is cloudy. The availability of exemplary recoveries under the Act was first proclaimed in dictum in 1939 on the basis that the action sounded in tort so that punitive damages were recoverable. ${ }^{94}$ Subsequent cases have adhered to this rationale. ${ }^{05}$ In the leading case, Basista $v$. Weir ${ }^{90}$ the Third Circuit justified a punitive award in only a paragraph, on the theory that it would serve a congressional purpose of "vindicating civil rights in civil suits." court neglected to explain precisely low punitive damages would vindicate civil rights, and subsequent cases allowing punitive dainages have relied on Basista without significantly clarifying their value. ${ }^{98}$

90. The purpose of the Acts was "to stamp out widespread violation of constitutional rights at virtually any cost. . . " Adikes v. S.H. Kress \& Co., 398 U.S. 144, 234 (1970) (Brennan, J., concurring and dissenting). See Gressman, The Unhappy History of Civil Rights Legislation, 50 Mich. L. Rev. 1323, 1332-36 (1952).

91. Act of Apr. 20, 1871, 1,17 Stat. 13, codified at 42 U.S.C. $\$ 1983$ (1970).

92. See, e.g., Hague v. CIO, 307 U.S. 496, 526-27 (1938) (Stone, J., concurring); Gressman, The Unhappy History of Civil Rights Legislation, 50 Mich. L. REv. 1323, 1336-43 (1952); Maslow \& Robinson, Civil Rights Legislation and the Fight for Equality, 1862-1932, 20 U. CHr. L. REv. 363, 370-73 (1953).

93. Some of these recoveries may have had penal facets. They did seem to exceed actual loss. See, e.g., Jackson v. Duke, 259 F.2d 3 (5th Cir. 1958) (plaintiff recovered $\$ 5,000$ after being beaten by police); Collum v. Butler, 288 F. Supp. 918 (N.D. Ill. 1968) (plaintiff proved $\$ 95$ in hospital bills and $\$ 650$ in lost wages resulting from a beating by the police and won a verdict of $\$ 17,500$; the court granted remittitur for $\$ 11,500$ ); Antelope v. George, 211 F. Supp. 657 (D. Idaho 1962) (plaintiff wrongly arrested for disturbing the peace and held for a few hours recovered $\$ 500$ ); Solomon v. Pennsylvania R.R., 96 F. Supp. 709 (S.D.N.Y. 1951) (a black woman forced to move to a different car on a train pursuant to the railroad's policies of segregation recovered $\$ 500$ for her public humiliation); cf. Rhoads v. Horvat, 270 F. Supp. 307 (D. Colo. 1967) (plaintiff arrested and detained 45 minutes by police awarded $\$ 5,000$ in compensatory damages in addition to $\$ 2,500$ in punitive damages by the court).

94. Hague v. CIO, 101 F.2d 774 (3d Cir.), modified, 307 U.S. 496 (1939). The court stated that "a right of action in the individual for damages for loss of political rights existed at common law. . . . Such an action sounds in tort and the jury may allow exemplary or punitive dainages." 101 F.2d at 789.

95. See Davis v. Board of Trustees, 270 F. Supp. 528, 531 (E.D. Ark. 1967); Antelope v. George, 211 F. Supp. 657, 660 (D. Idaho 1962); cf. Wills v. Trans World Airlines, 200 F. Supp. 360, 367 (S.D. Cal. 1961) (using the same logic under the Federal Aviatiou Act [see text accompanying note 103 infra]).

96. 340 F.2d 74 (3d Cir. 1965).

97. Id. at 86.

98. See Caperci v. Huntoon, 397 F.2d 799, 801 (1st Cir.), cert. denied, 393 U.S. 940 (1968); Mausell v. Saunders, 372 F.2d 573, 576 (5th Cir. 1967); Sostre v. Rockefeller, 312 F. Supp. 863, 885-86 (S.D.N.Y. 1970); Rhoads v. Horvat, 270 F. Supp. 307, 


\section{Federal Aviation Act}

The Federal Aviation Act $(F A A)^{99}$ is a general statute dealing with regulation of airlines. Section $404(\mathrm{~b})^{100}$ of the Act forbids "unreasonable" or "unjust" discrimination by an airline against coach passengers in favor of first-class passengers. In Wills $v$. Trans World Airlines, Inc., ${ }^{101}$ a district court implied a right of action under the Act on the ground that damages in state law actions for breach of contract are predictably small, and because the Civil Aeronautics Board cannot efficiently punish violators. ${ }^{102}$ It also allowed a punitive recovery, both on the principles that justified implying the civil remedy and on the traditional availabilty of punitive damages in tort. ${ }^{103}$ The court stated that the punitive award was desigued to complement the criminal provisions of the Act. ${ }^{104}$

\section{III}

\section{Functional Analysis of Punitive Awards}

\section{A. Compensation}

A punitive award can compensate the plaintiff for any injuries not satisfactorily included in the compensatory award. The common law at one time did not compensate for nonfinancial injuries, such as pain and suffering or mental anguish, ${ }^{105}$ and some courts allowed recoveries

310 (D. Colo. 1967); Washington v. Official Court Stenographer, 251 F. Supp. 945, 947 (E.D. Pa. 1966); Tracy v. Robbins, 40 F.R.D. 108, 113 (D. S. Car. 1966); cf. Guido v. City of Schenectady, 404 F.2d 728, 739-40 (2d Cir. 1968) (Waterman, J., dissenting); Globus v. Law Research Serv., Inc., 287 F. Supp. 188, 194 (S.D.N.Y. 1968), rev'd, 418 F.2d 1276 (2d Cir. 1969).

99. 49 U.S.C. $\S \S 1301-1542$ (1970). The Act provides a general framework for regulation of the airline industry. For example, it defines the duties and sets up procedures to choose inembers for the Civil Aeronautics Board, establishes the Federal Aviation Administration and defines its powers, makes provision for regulation and registration of air carriers, and sets up procedures for investigation of air accidents. 100. 49 U.S.C. $\S 1374(b)(1970)$.

101. 200 F. Supp. 360 (S.D. Cal. 1961). Plaintiff, a coach passenger with a reservation from St. Louis to Los Angeles, was "bumped" in favor of a first-class passenger whose reservation was made later than the plaintiff's, when the plane was found to be oversold. He had to wait four hours for another flight and to call his wife to advise her of the change. He was awarded less thau two dollars in compensatory damages and $\$ 5,000$ in punitive damages. Id. at 368 .

102. Id. at $364-65$.

103. Id. at 367 , citing Hague v. CIO, 101 F.2d 774 (3d Cir. 1939) (asserting that punitive damages are available under the Civil Rights Act because they were available at cominon law). See text accompanying notes 94-95 supra.

104. Id. at 368 .

105. A. Sedgwick, Elements of Damages 98-106 (2d ed. 1909); 1 T. Sedgwick, supra note $11, \S 43 ; 1$ J. SUTHERLAND, A TREATISE ON THE LAW OF DaMages $\$ \S 21-24$ (4th ed. 1916). Cf. United States Steel Corp. v. Lainp, 436 F.2d 1256, 1276-79 (6th Cir. 1970) (refusing to allow recovery to widow of sailor for loss of consortium in Jones Act suit). 
for these losses under the heading of punitive damages, at least from defendants guilty of gross misconduct. ${ }^{106}$ Because the measure of coinpensatory damages has been substantially liberalized, however, this traditional compensatory function has becone obsolete. ${ }^{107}$

Punitive damages can also be used to indemnify the plaintiff for his litigation expenses. ${ }^{108}$ This can be of importance under those federal statutes where, typically, poor plamtiffs seek small compensatory awards, ${ }^{109}$ because the expense of suing could otherwise essentially deny these statutory remedies to their intended recipients. The courts might use their equitable jurisdiction to award counsel fees, ${ }^{110}$ but such awards are said to be appropriate only in exceptional circumstances. ${ }^{111}$

106. See, e.g., Wise v. Daniel, 221 Mich. 229, 190 N.W. 746 (1922); Fay v. Parker, 53 N.H. 342 (1873). These courts distinguished punitive recoveries designed to punish the defendant, thought by the New Hampshire court to violate the constitutional proscription of double jeopardy [53 N.H. at 385-97], from exemplary recoveries to compensate for imsulted honor and lacerated sensibilities, which werc acceptable [id. at 380-84].

107. See Note, Exemplary Damages in the Law of Torts, 70 Hanv. L. Rev. 517, 520 (1957).

108. One state court has adopted indemnification as the sole justification for punitive awards. Doroszka v. Lavine, 111 Conn. 575, 578, 150 A. 692, 693 (1930). Others have allowed juries to consider litigation costs in fixing the amount of punitive damages. See New Orleans, J. \& G.N.R.R. v. Albritton, 38 Miss. 242, $272-73$ (1859); cf. New York, C. \& St. L.R.R. v. Grodek, 127 Ohio St. 22, 186 N.E. 733 (1933). The multiple recoveries available under some federal statutes may also reflect a compensatory urge. See note 1 supra.

109. Cf. Rice, Exemplary Damages in Private Consumer Actions, 55 Iows L. Ruv. 307,337 (1969) (suggesting that punitive awards may be one solution to the problem of costs in litigation of consumer actions).

110. A court of equity is said to have the power to award attorneys' fees in appropriate cases. See Vaughan v. Atkinson, 369 U.S. 527, 530-31 (1962); Bell v. School Bd., 321 F.2d 494, 500 (4th Cir. 1963). For treatment of the question in a suit by a union member against a union, charging violation of LMRA, see Rolex v. Atlantie C.I.R.R., 186 F.2d 473, 481 (4th Cir. 1951):

The justification here is that plaintiffs of small means have been subject to discriminatory and oppressive conduot by a powerful labor organization which was required, as bargainmg agent, to protect their interests. The vindication of their rights necessarily involves greater expense in .... [carrying on important and extended] litigation than the amount involved to the imdividual plaintiffs would justify their paying. In such situations, we think that the allowance of counsel fees in a reasonable amount as a part of the recoverable costs of the case is a matter resting in the sound discretion of the trial judge. Cf. Mills v. Electric Auto-Lite Co., 396 U.S. 375 (1970) (recovery of attorneys' fees allowed in derivative action under Securities Acts to earry out congressional intent to make effective remedy available); Lee v. Southern Home Sites Corp., 444 F.2d 143 (5th Cir. 1971) (recovery of attorneys' fees allowed under Civil Rights Acts).

Of course, courts could only make such awards under federal statutes when they had equitable jurisdiction, but under at least some statutes they do. The Civil Rights Act, for example, allows federal courts to entertain both actions at law and suits in equity. 42 U.S.C. $\$ 1983$ (1970). Similarly, LMRDA can be interpreted to give the courts equitable jurisdiction. Gartner v. Soloner, 384 F.2d 348, 354-55 (3d Cir. 1967).

111. Kahan v. Rosenstiel, 424 F.2d 161, 167 (3d Cir. 1970). Such cireunustances are said to be present only where the defendant is guilty of flagrant misconduct. Sec, 
Furthermore, since Congress has specifically provided for such awards under some statutes, such as the Securities Acts, ${ }^{112}$ courts may infer that they are not available without express sanction.

This has happened under LMRDA, a statute under which recovery of litigation costs could be important. ${ }^{113}$ Several courts have recognized this need but nevertheless have felt compelled to deny counsel fees because there is no express provision for them in the Act. ${ }^{114}$ One court, lowever, made such an award to ease the plight of "a single unionist fighting his lonely battle for justice." 115 A punitive award of litigation costs might be a satisfactory way of circumventing reservations about legislative imtent. Similarly, punitive recoveries under FAA could be justified on a compensatory rationale because of the expense to the ordimary hitigant of satisfying a small claim against the legal department of a large airline. In Wills v. Trans World Airlines, Inc., ${ }^{116}$ for example, the plaintiff was able to recover only nominal compensatory damages; without the possibility of a punitive recovery he probably would not have sued.

Under other statutes, however, concern for emasculation of the remedy is not justified. Class actions under the Securities Acts, for example, can yield large recoveries, and the Second Circuit cited this possibility as a reason for rejecting punitive dainages under the 1933 Act. ${ }^{117}$ Another example is provided by LMRA suits, which are usually carried out by unions and employers fully able to pay for protracted litigation. Indeed, they are often primarily designed to get injunctions, in which case recovery of damages is not a determinative factor in the decision to sue. Finally, the availability of large recoveries under FELA also

e.g., Vaughan v. Atkinson, 369 U.S. 527, 530-31 (1962) (defendants "callous" in their refusal to compensate plaintiff for his injuries); Bell v. School Bd., 321 F.2d 494, 500 (4th Cir. 1963) (plaintiff forced to go to court by defendant's "unyielding refusal" to comply with court's holding that segregation must end).

112. 15 U.S.C. $\$ \$ 77 \mathrm{k}(\mathrm{e})$ [1933 Act], 78r(a) [1934 Act] (1970).

113. One of the objections to its provisions raised on the floor of Congress was that it failed to compensate the wronged worker for the cost of litigation. Thus Senator Goldwater protested:

Although the Bill permits the union member himself to sue for infringement of his rights, the nature of the suit is such as to promise, even if successful, hittle in the way of monetary damages except in the rare case where the plaintiff's job rights or job tenure have been adversely affected. Moreover, the Bill does not grant him, even where successful in his suit, reasonable counsel fees or other costs.

Quoted in McCraw v. United Ass'n of Journeymen \& Apprentices of Plumbing, $216 \mathrm{~F}$. Supp. 655, 664 n.3 (E.D. Tenn. 1963).

114. See McGraw v. United Ass'n of Journeyınen \& Apprentices of Plumbing, 216 F. Supp. 655, 664 (E.D. Tenn. 1963); Vars v. International Bhd. of Boilermakers, 215 F. Supp. 943, 952 (D. Conn. 1963).

115. Gartner v. Soloner, 384 F.2d 348, 355 (3d Cir. 1967).

116. 200 F. Supp. 360,368 (S.D. Cal. 1960). See also note 101 supra.

117. Globus v. Law Research Serv., Inc., 418 F.2d 1276, 1285 (2d Cir. 1969). 
makes the cost of suing worthwhile. ${ }^{118}$ Although the infrequency with which claims are brought to trial ${ }^{110}$ may indicate that the expense deters suits, the plethora of suits under FELA since its passage demnonstrates that awarding attorneys' fees is not essential to compensating injured railroad workmen. ${ }^{120}$ Indeed, fear of einployer retaliation seeins a far greater deterrent to initiating suits than the cost of hitigation. ${ }^{121}$ It is understandable, therefore, that the Kozar court did not intimate any compensatory rationale in inaking its award.

\section{B. Retribution ${ }^{122}$}

Although commentators have frequently suggested retribution as one purpose for punitive awards, ${ }^{123}$ courts have rarely explicitly rested their decisions on it, probably because they feel that inere pumishment is not a proper goal for the law. ${ }^{124}$ Nevertheless, courts continue to

118. For example, Chiet reports that in death cases the average recovery in his sample was $\$ 26,150$. E. CHIET, INJURY AND RECOVERY IN THE COURSE OF EMPLOYMENT 193 (1961). He adds that "[t]he lawsuits seem to involve the larger cases. In those cases in which a verdict was rendered, the average amount was $\$ 44,674 . "$ Id . at 194. Cases involving less money are usually settled out of court. Here, of coursc, availability of a "compensatory" punitive remedy might result in higher settlements for the plaintiffs.

Other problems under FELA did threaten the effectiveness of its compensatory remedy. For example, the federal courts originally interpreted the Act to allow suits only at the home of the employer, and Congress had to specify that they could be brought in any district where the railroad did business. In urging passage of the bill, the Senate Judiciary Committee said, "The extreme difficulty, if not impossibility, of a poor man who is injured while in railroad employ securing the attendance of the necessary witnesses at such a distant point makes the remedy given by the law of little avail under such circumstances." S. ReP. No. 432, 61st Cong., 2d Sess. 4 (1910).

119. Chiet reports that of every 25 FELA claims, fewer than two go to trial. E. CHIET, supra note 118, at 201, Table 7.6.

120. During the fiscal year 1970 , for example, there were 1,272 civil cases commenced in federal courts under FELA. ANNUAL REPORT OF THE DiRECTOR OF THE Administrative Office of the United States Courts 1970231 (1971). Since these figures do not include the number of FELA suits brought in state courts, it is clear that the cost of suing has not entirely nullified the effectiveness of the compensatory remedy. Under LMRDA, by comparison, there were only 121 suits. Id. at 233.

121. E. CHIET, supra note 118, at 203 ("Rightly or wrongly, employees often believed that prosecution of a claim was a sure way to dismissal").

122. On the longevity of the natural human desire to punish persons who do wrong, see H. PaCker, The Limits of the Criminal Sanction 9-11 (1968).

123. See, e.g., Note, Exemplary Damages in the Law of Torts, 70 HARv. L. REv. 517, 521-22 (1957); Comment, The Imposition of Punishment by Civil Courts, 41 N.Y.U.L. Rev. 1158, 1161-62 (1966); Comment, Punitive Damages and Their Possible Application in Auto Accident Litigation, 46 VA. L. Rev. 1036, 1039-41 (1960).

124. "Retribution is no longer the dominant objective of the criminal law." Williams v. New York, 337 U.S. 241, 248 (1949). One commentator concluded his discussion of retributive awards with the observation that "a modern legal system can hardly be based on revenge." Note, Exemplary Damages in the Law of Torts, 70 HARV. L. REV. 517, 522 (1957). For a contrary view on the proper purposes of criminal law, see generally Armstrong, The Retributivist Hits Back, 70 MiND 471 (1961); 
stress the outrageousness of the defendant's acts as an important element in some punitive awards, ${ }^{125}$ and some courts expressly recognize punitive awards as a form of expressing community outrage. ${ }^{126}$ It is apparent that some tinge of the retributive urge remains. Thus, although the courts generally reject punishment for punishment's sake, retribution may be the basic motive behind punitive awards ostensibly made on other grounds. A review of analyses of criminal punishment and punitive awards under some federal statutes suggests two possible explanations of judicial willingness to use punitive awards for retributive purposes: first, to deter self-help; and second, to vindicate important rights and to stigmatize violation of these rights.

At the outset, it should be observed that under some federal statutes a retributive purpose is improper. Implied private actions under the Securities Acts, for example, were permitted to deter violations, not to punish wrongful conduct, and retributive awards are therefore unjustified in such actions, although some courts have intimated otherwise. ${ }^{127}$ Another example is LMRA, which was designed to further industrial peace. Giving judicial recognition to the kind of inoral distinctions involved in retributive awards would exacerbate relations between unions and employers and thereby contravene the central purpose of the Act. ${ }^{128}$ The Third Circuit's rejection of punitive damages where, as it

Gerber \& McAnany, Punishment: Current Survey of Philosophy and Law, 11 ST. Louis U.L.J. 491, 496-502 (1967). Consider A. GoodHART, ENGLISH LAW AND THE MORAL LAW 92-93 (1953):

There seems to be an instinctive feeling in most ordinary men that a person who has done an injury to others should be punished for it. As civilization develops this feeling is limited to intentional or negligent mjuries, but the principle remains the same. It has, therefore, been pointed out that if the criminal law refuses to recognize retributive punislunent then there is a danger that people will take the law into their own hands. A far greater danger, to my mind, is that without the sense of retribution we niay lose our sense of wrong. Retribution in punishment is an expression of the community's disapproval of crime, and if retribution is not given recognition this disapproval may also disappear. A community which is too ready to forgive the wrongdoer way end up by condoning the crime.

125. As Prosser says, the focus is still on whether the defendant's conduct "has the character of outrage frequently associated with crime." W. PROSSER, A HANDBOOK OF THE LAW OF TORTS $\$ 2$, at 9 (1964). For recent discussions of the importance of outrageous conduct to justify punitive awards, see Sweany v. United Loan \& Fin. Co., 205 Kan. 66, 468 P.2d 124 (1970); Mid-Continent Refrigerator Co. v. Straka, 47 Wis. 2d 739, 178 N.W.2d 28 (1970); Gordan v. Nationwide Mut. Ins. Co., 62 Misc. 2d 689, 309 N.Y.S.2d 420 (Sup. Ct. 1970).

126. Some courts have suggested that punitive danıages may constitute a kind of public revenge by giving vent to the jnry's indignation at the defendant's conduct. See Gostkowski v. Roman Catholic Church of the Sacred Hearts, 262 N.Y. 320, 324-25, 186 N.E. 798, 800 (1933); Wilkes v. Wood, 98 Eng. Rep. 489, 499 (C.P. 1763 ).

127. See cases cited note 81 supra.

128. Consider the objections of fonner Chief Justice Warren to allowing state law punitive recoveries for labor conflicts:

The parties to labor controversies lave enough devices for naking one an- 
stressed, the only purpose of the award would be to punish the employer for his breach of contract ${ }^{129}$ can be explained as a rejection of retribution consistent with the policies of the Act.

Under the other federal statutes discussed in part II, there is no sucl threshold barrier to retribution. LMRDA, for example, was not designed to achieve industrial peace, and the analogy with LMRA adopted by one court to exclude punitive recoveries is inapposite. ${ }^{130}$ Similarly, punitive awards under the Civil Rights Act and even FELA can be examined under the self-help and vindication theories suggested above.

\section{The Revenge Theory}

Some early English courts attempted to dissuade people from dueling by offering punitive awards as a form of judicial revenge for provocative conduct. ${ }^{131}$ Although, as the practice of dueling receded, express rehance on deterring self-help was abandoned, punitive awards should still be able to provide an effective alternative to personal revenge for victims of illegal conduct. Furtherinore, social tensions created in the community at large by the wrongful behavior may be assuaged when a jury awards punitive dainages to punish the defendant.

The statutes under whicl courts liave allowed seemingly retributive awards cover situations that problably present dangers of self-help, and it appears that the revenge theory is a factor in such awards. Civil rights suits, for example, frequently grow out of already violent confrontations with police. ${ }^{132}$ Furthermore, the victims of alleged police mistreatment

other "smart" without this Court putting its stamp upon another. I cau conceive of nothing more disruptive of congemal labor relations than arming employee, union and management with the potential for "smarting" one another with exemplary damages.

UAW v. Russell, 356 U.S. 634, 653 (1958) (dissenting opimion). A similar concern with avoiding retribution is evident in decisions under other sections of the Act. Thus, for example, the Supreme Court has held that the National Labor Relations Board does not have power to penahize parties for their unfair labor practices under 29 U.S.C. $\S 160$ (c) (1970) because "[t]he Act does not prescribe penalties or fines in vindicatiou of public rights. . . " Republic Steel Corp. v. NLRB, 311 U.S. 7, 10 (1940).

129. United Shoe Workers Local 127 v. Brooks Shoe Mfg. Co., 298 F.2d 277 (3d Cir. 1962).

130. See note 68 supra and accompanying text.

131. Merest v. Harvey, 128 Eng. Rep. 761 (C.P. 1814); Grey v. Grant, 95 Eng. Rep. 794 (C.P. 1764). See also Alcorn v. Mitchell, 63 Ill. 553, 554 (1872) (punitive damages allowed against defendant who spat in plaintiff's face in public, because "the public tranquility may be preserved by saving the necessity of resort to personal violence as the only means of redress").

132. See, e.g., Basista v. Weir, 340 F.2d 74 (3d Cir. 1965) (plaintiff assaulted by police in his home); Jackson v. Duke, 259 F.2d 3 (5th Cir. 1958) (plaintiff assaulted and beaten by pohce); Sostre v. Rockefeller, 312 F. Supp. 863 (S.D.N.Y. 1970) (black mihtant prisoner unjustly held in solitary for 13 months because of his political views); Collum v. Butler, 288 F. Supp. 918 (N.D. Ill. 1968) (plaintiff, arrested for drunken 
are likely to be outraged: at least one court has noted the "zeal" with which the plaintiff in a Civil Rights Act suit sought to vindicate his rights. ${ }^{133}$ This zeal might easily be translated into attempts at revenge; indeed, the recent outbreak of violent attacks on police can be traced in part to perceived police violations of civil rights. ${ }^{134}$

Similarly, LMRDA claims frequently arise from potentially violent personal conflicts between umion officials and plaintiffs deprived of their livelihoods. ${ }^{135}$ Thus, allowing punitive recoveries where the defendant has acted maliciously, as the courts seem willing to do, may have the salutary effect of reducing social conflict.

Under FELA self-help is considerably less likely than under LMRDA and the Civil Rights Acts, but it is still present when the employer's misconduct becomes sufficiently aggravated. Thus, the general state court standard that an employer's conduct must be quasi-criminal in order to justify recovery of punitive dainages by an employee may represent general recognition of the dangers of self-help under such circumstances. ${ }^{130}$ Similarly, the Kozar court supported its conclusion that the railroad's conduct was quasi-criminal with evidence of the sort of behavior-refusal to repair dangerous tools after repeated requests, ap-

driving and resisting arrest, unable to work for one month as a result of beating received from police); Brooks v. Moss, 242 F. Supp. 531 (W.D. S. Car. 1965) (defendant, acting as magistrate's constable, assaulted plamtiff with blackjack).

133. Rhoads v. Horvat, 270 F. Supp. 307, 311 (D. Colo. 1967) ("In the case at bar we do not doubt that the plaintiff was outraged by the arrest. His main reaction was one of zeal to uphold the right which had beeu invaded").

134. See Report of the National Advisory Commission on Civil Disorders 157-61 (1968); Comment, Socio-Legal Aspects of Racially Motivated Police Misconduct, 1971 Duke L.J. 751, 751-68; see generally THE WALKER REPORT TO THE NAtional Committee on the Causes and Prevention of Violence: Rights in CoNFLICT (1968). For a discussion of the difficulties of enforcing criminal sanctions against civil rights violators, which is a possible alternative mode of revenge, see Caldwell \& Brodie, Enforcement of the Criminal Civil Rights Statutes in Prison Brutality Cases, 52 Gro. L.J. 706 (1968).

135. In some cases actual violence has already erupted. In International Bhd. of Boilermakers v. Braswell, 388 F.2d 193 (5th Cir. 1968), for exainple, plaintiff was expelled from his local after a fist fight with the business manager of the local. Similarly, in McCraw v. United Ass'n of Journeymen and Apprentices of Pluinbing, 216 F. Supp. 655 (E.D. Tenn. 1963), plaintiff was expelled and put out of a local meeting by force, which resulted in injuries to him for which he later sought to recover damages.

In other cases, the threats to livelihood combined with personality conflicts make violence a real possibility. See, e.g., International Bhd. of Boilermakers v. Rafferty, 348 F.2d 307 (9th Cir. 1965) (plaintiffs expelled because they opposed proposals made by officer of local); Cole v. Hall, 35 F.R.D. 4 (E.D.N.Y. 1964) (plaintiff alleged he was ousted for being critical of the president of the local); Burris v. International Bhd. of Teamsters, 224 F. Supp. 277 (W.D.N. Car. 1963) (plaintiff blacklisted for objecting to handling of local's affairs).

136. See, e.g., Whitehead v. Salyer, 346 F.2d 207 (10th Cir. 1965) (Texas law); Sumski v. Sauquoit Silk Co., 66 Lack. Jur. 118, 125 (Pa. Com. Pl. 1965) ("The purpose of punitive damages is to punish the evil doer"); Sheffield Div., Armco Steel Corp. v. Jones, 376 S.W.2d 825 (Tex. 1964). 
parently false claims that repair records had been stolen, and callous indifference to the continuing danger of the offending crane even after the fatal accident ${ }^{137}$ - that would seem most likely to provoke a violent response from the employees.

It may well be, of course, that the danger of self-help that originally underlay the rule of law justifying punishment of quasi-criminal behavior is greatly attenuated in the relatively law-abiding society of today. Punitive awards on this basis should therefore be restricted to statutory violations that are truly likely to provoke violent responses from either the plaintiff or others. ${ }^{138}$

\section{The Important-Federal-Right Theory}

Another explanation of the retributive urge evident under some statutes is that these statutes protect rights of great importance. In fact, the first Enghish case allowing punitive danıages, Huckle v. Money, ${ }^{130}$ actually relied on this theory. The court there allowed punitive damages against an officer who executed a general warrant that empowered its bearer to arrest anyone, because the right not to be arrested indiscriminately was of fundamental importance. The court said that violation of this right "is worse than the Spanish Inquisition; a law under which no Englishman would wish to live an loour."140

Although American courts have rarely made express distinctions among varieties of rights when considering punitive damages, they have done so in other contexts. The Supreme Court, for example, has often stressed that certain rights, such as the right to vote ${ }^{141}$ and the guarantee of free speech, ${ }^{142}$ are of prime importance. These and similar rights are protections of the individual against misuse of governnient power, ${ }^{143}$

137. See text accompanying notes 12-13 supra.

138. Courts should not look only to a given plaintiff to estinate the danger of self-help, because others in a similar situation might be outraged and seek revenge even though a particular plaintiff is too law-abiding or in too weak a position to retaliate. Therefore, the focus should be on whole areas of law, such as Civil Rights Act cases or FELA cases, to determine if self-help is a real danger in the area.

139. 95 Eng. Rep. 768 (C.P. 1763).

140. Id. at 769 .

141. E.g., Kramer v. Union Free School Dist., 395 U.S. 621, 626 (1969): "Any unjustified discrimination in determining who may participate in political affairs or in the selection of public officials undermines the legitimacy of representative government." Federal legislation has reflected a corresponding concern with voting. Sec Voting Rights Act of 1965, Pub. L. No. 89-110, 79 Stat. 437, codified at 42 U.S.C. $\S 1973$ (1970).

142. E.g., Kovacs v. Cooper, 336 U.S. 77, 88 (1949) (speaking of "the preferred position of freedom of speech"), citing Thomas v. Collins, 323 U.S. 516 (1945); Murdock v. Pennsylvania, 319 U.S. 105 (1943).

143. This was apparently an early concern of courts: "Historically, oppressive conduct by public officers was the situation where early judges were most prone to sanc- 
which has long been an American concern. ${ }^{144}$ Some punitive damages decisions reflect a similar concern for the value of the rights involved. In Wayne $v$. Venable, ${ }^{145}$ for example, plaintiff was deprived of the right to vote and recovered $\$ 2,000$ in compensatory damages although he made no showing of actual loss. The court upheld the award because "[i]n the eyes of the law this right is so valuable that damages are presumed for the wrongful deprivation of it."146

Federal courts might wish to offer exemplary recoveries to punish violators of important rights because such awards would stress the importance of the violated right. ${ }^{147}$ Courts awarding punitive dannages under the Civil Rights Acts seemingly have had such considerations in mind. In Basista v. Weir, ${ }^{148}$ the Third Circuit set out to "vindicate" federal rights and cited Wayne $v$. Venable ${ }^{149}$ for the proposition that different treatment should be accorded violations of important rights. Since it felt that protections against the illegal arrest and wrongful incarceration involved in Basista were as important as the right to vote at issue in Wayne, the court upheld the punitive award. ${ }^{150}$ This treat-

tion exemplary damages, and by which they justified and rationalized the doctrine." C. MCCORMICK, supra note $26, \S 81$ at 288 .

144. See 5 Writings of James Madson 371-85 (G. Hunt ed. 1904). Former Justice Harlan recently pointed out that "the Bill of Rights is particularly imtended to vindicate the interests of the individual in the face of the popular will as expressed in legislative inajorities." Bivens v. Six Unknown Agents, 403 U.S. 388, 407 (1971) (concurring opimion). Cf. T. SeDGwICK, supra note 11, \& 354: "[The use of punitive damages] has its roots in that jealousy of the exercise of arbitrary and malicious power, to which the jury in our system of law has always been so keenly alive."

145. 260 F. 64 (8th Cir. 1919). Cf. Wiley v. Sinkler, 179 U.S. 58 (1900) (upholding the recovery of $\$ 2,500$ by a plaintiff deprived of his right to vote); Scott v. Donald, 165 U.S. 58 (1897) (holding that the jurisdictional amount for federal diversity jurisdiction was properly invoked by a plaintiff who claimed $\$ 6,000$ damages for the temporary seizure of his hquor by constables acting under an unconstitutional state prohibition statute, although his eventual recovery was only $\$ 300$ ); Nixon v. Herndon, 273 U.S. 536 (1927) (holding that a common law right to sue for damages due to deprivation of a political right such as the right to vote may be exercised in the federal courts); Wilkes v. Wood, 98 Eng. Rep. 489 (C.P. 1763) (stressing the value of public revenge).

146. $260 \mathrm{~F}$. at 66 .

147. One product of this reaffirmation of the importance of the right is to reassert the violated norm as the natural order, to which all men can be expected to adhere unconsciously. Thus any kind of punishment may lead to an "end product of behiefs crystalized into habits of action on the part of all human beings participating . . . in the punishment process." W. Clark \& W. Marshall, Crimes $\$ 2.00$, at 70 (rev. ed. Wingersky 1958).

148. 340 F.2d 74 (3d Cir. 1965).

149. 260 F. 64 (8th Cir. 1919).

150. 340 F.2d at 81 , citing Nixon v. Herndon, 273 U.S. 536 (1927); Wiley v. Sinkler, 179 U.S. 58 (1900); cf. Comment, Use of $\$ 1983$ to Remedy Unconstitutional Police Conduct, 5 Harv. Civ. Rughrs-Civ. Lib. L. Rev. 104, 119 (1970):

Police misconduct like citizen misconduct, should be prosecuted. Yet, in fact, police misconduct is even more intolerable both because it engenders 
ment seems justified, because protection of these rights is now felt to be an extremely important national goal. Enduring congressional concern with these rights is indicated by the passage of other Civil Rights Acts $^{151}$ and the independent effort to provide criminal sanctions for their violation. ${ }^{152}$ Public condemnation of Civil Rights Act violations through retributive awards thus may be one method of increasing public respect for the underlying rights, and this is extremely important in an age of disaffection with constitutional protections.

There is soine evidence that courts have taken a similar approach to claims for punitive damages under LMRDA. This statute provides protections for union members against misuse of power by union officials, which Congress felt to be extremely important. ${ }^{153}$ Since unions can exercise almost as nuch control over their members as government does over citizens, these protections can be viewed as analogous to constitutional protections of liberty, and some courts have apparently adopted the analogy in the context of punitive dainages. Thus, one court has described the statute's protections as "fundainental to the preservation of the democratic process in labor organizations."154 Similarly, the Fifth Circuit stressed the importance of the rights involved in upholding a punitive award. ${ }^{155}$

FELA, by comparison, does not merit such special treatment. Its protections for the workman are not equally essential to the political process or to the individual's everyday life. Thus, the Kozar court did not concern itself with the importance of this protection, but rather

retaliatory citizen misconduct and because it leaves the polity defenseless when the law enforcers become the law violators.

151. Congress has enacted mueh significaut legislation dealing with civil rights in the last decade and a half. E.g., Civil Rights Act of 1957, Pub. L. No. 85-315, \& 131, 71 Stat. 634, codified at 42 U.S.C. \$ 1971 (1958); Civil Rights Act of 1960, Pub. L. No. 86-449, § 601, 74 Stat. 86, amending 42 U.S.C. \$ 1971 (1958); Civil Rights Act of 1964, Pub. L. No. 88-352, § 101, 78 Stat. 241, amending 42 U.S.C. \& 1971 (Supp. III 1961); Voting Rights Act of 1965, Pub. L. No. 89-110, 79 Stat. 437, codified at 42 U.S.C. $\$ 1973$ (1970); Civil Rights Act of 1968, Pub. L. No. 90-284, $\S 101,82$ Stat. 73 , codified at 18 U.S.C. $\$ 245$ (1970).

152. 18 U.S.C. $\S 242$ (1970) imposes a criminal sanction on any person who willfully violates the civil rights of another person under color of state law.

153. See note 65 supra.

154. Cole v. Hall, 35 F.R.D. 4, 8 (E.D.N.Y. 1964).

155. International Bhd. of Boilermakers v. Braswell, 388 F.2d 193, 200 (1968), quoting Fittipaldi v. Legassie, 18 App. Div. 2d 331, 337, 239 N.Y.S.2d 792, 796 (1963):

The very basis for the existence of unionism in our society today is the promise of employment to those who desire to associate freely in order to obtain it. The right of the working man to the benefits of collective bargaining is too essential and valuable to be hindered, impeded and seriously damaged by irresponsible or dictatorial leaders. . . .

Cf. Affeldt, The Labor Bill of Rights, Its Impact Upon Personal Rights, 37 U. DeT. L.J. 500 (1960). 
with the gross inisconduct of the railroad, an integral element of the revenge theory.

\section{Deterrence}

Most courts that allow punitive awards under federal statutes claim to do so in order to deter violations. Under some statutes, indeed, deterrence may be the only permissible objective. Thus, when the Second Circuit rejected punitive awards in implied actions under the 1933 Securities Act, it discussed only the deterrent function. ${ }^{156}$ Similarly, the pumitive award under section 301 of LMRA in Sidney Wanzer \& Sons, Inc. v. Milk Drivers' Local $753^{157}$ was not inconsistent with the Third Circuit's earlier denial of punitive recoveries under LMRA, ${ }^{158}$ because it was made for a deterrent purpose. While punishment of the einployer was the only objective before the Third Circuit, the award in Wanzer would predictably liave influenced the employer not to violate the Act in its future dealings with the union and therefore furthered rather than endangered industrial peace.

The courts that claim deterrence as their objective, lowever, often do not explain why they expect punitive awards to operate as effective deterrents to statutory violations. The effectiveness of deterrence by punishment depends upon a basically Benthamite rationality on the part of the person to be deterred-that he weigh the advantages of certain conduct against its disadvantages in deciding whether to embark upon it. ${ }^{169}$ Commentators have argued that this model of human behavior does not reflect reakity, because lrumans do not behave so rationally and because the threat of punishment is often ineffective to outweigh the immediate appeal of illegal gratification. ${ }^{160}$ Evaluating the deterrent effectiveness of a punitive award in this perspective therefore raises two related questions: first, are inost defendants under a given statute likely to respond to a monetary penalty; and second, would such an exaction be superfluous in light of other available sanctions?

\section{Responsiveness to Monetary Sanctions}

Unless potential violators will observe the law because of the threat of punitive awards, sucl awards cannot be justified as deterrents to un-

156. See Globus v. Law Research Serv., Inc., 418 F.2d 1276, 1284-85 (2d Cir. 1969).

157. 249 F. Supp. 664 (N.D. Ill. 1966).

158. United Shoe Workers Local 127 v. Brooks Shoe Mfg. Co., 298 F.2d 277 (3d Cir. 1962).

159. See J. Bentham, Theory of Legislation 324-27 (1931).

160. See Barnes \& Teeters, New Horizons in Criminology $371-456$ (2d ed. 1951); Gardiner, The Purposes of Criminal Punishment, 21 Modern L. Rev. 117, 122-25 (1958). See generally S. Kadish \& M. Paulsen, Criminal LaW aNd Its Processes 63-94 (2d ed. 1969). 
lawful conduct. LMRDA, for example, presents a situation in which the assumption of deterrence should not be made without question. Defendants may sometimes act out of prejudice or personal animus. Status within the union is likely to be a more important consideration to potential violators than the danger of punitive recoveries from the union treasury. Thus, the bald assertion of the Fifth Circuit that punitive awards are allowed under LMRDA because they will deter ${ }^{101}$ is certainly debatable, and it is likely that the court was really more interested in retribution, particularly in light of the stress placed by the court on the importance of the rights involved. ${ }^{162}$ Similar problems of social status and prejudice complicate analysis of the deterrent effect of monetary awards under the Civil Rights Acts.

Typical FAA, FELA, or Securities Act defendants are much more likely to respond to nonetary sanctions, since money is the motivating force behind their conduct in the first place. Potential wrongdoers under FAA and FELA can be expected to contemplate alternative courses of conduct more carefully and rationally because they conduct ongoing businesses and inust consider costs beforehand. Additionally, the level of legal awareness among large corporations inakes it likely that a punitive award against one will enter into the contemplations of all, further justifying a deterrent effort. News of the award in Kozar, for example, has probably reached all carriers in the country. Thus, the punitive awards given under these statutes can be justified on a deterrent rationale, and the Kozar court, not surprisingly, adopted deterrence as the common law reason for its award. ${ }^{103}$

\section{Effect of Other Sanctions}

The deterrent effect of a punitive award may be insignificant even where the violator is otherwise likely to be responsive to monetary sanctions if there are other sanctions for his wrongful conduct. The most important type of such other sanctions is the compensatory award, which, as commentators have observed, does burden wrongful conduct when it is based on fault, ${ }^{164}$ and which may have distinctly penal facets

161. International Bhd. of Boilermakers v. Braswell, 388 F.2d 193, 200 (1968).

162. See note 155 supra.

163. The importance courts have given to enterprise accountability under FELA highlights their concern with deterrence, because deterring an enterprise is only valuable where the defendant can control the wrongful conduct, while this factor is not crucial to merely punishing it. In United States Steel Corp. v. Fuhrman, 407 F.2d 1148 (6th Cir. 1969), for example, the appeals court, concentrating on deterrence, reversed a punitive award because it did not feel that the corporation, from its home offices in Pittsburgh, could effectively control the conduct of its captains on the Great Lakes. Therefore, a punitive award would in all likelihood not reduce violations. Kozar's reliance on Fuhrman implies that it was also primarily concerned with deterrence.

164. See Morris, Punitive Damages in Tort Cases, 44 HARv. L. Rev. 1173, 1173-76 
under some federal statutes. ${ }^{165}$ Especially where multiple suits are likely, as some courts have noted, ${ }^{166}$ compensatory awards can suffice for deterrent purposes. The likelihood of extremely burdensome recoveries under some statutes may therefore rule out punitive damages because they serve no purpose. Of course, insurance against compensatory awards may lessen their deterrent effect. Also, compensatory awards cannot be considered equivalent to punitive damages where the standard of conduct for punitive recoveries differs from that invoked in compensatory awards. ${ }^{167}$

Fines and imprisonment are sanctions of similar importance in evaluating the effectiveness of deterrence by punitive awards; it is probably wise to exclude punitive damages from statutory schemes under which the deterrent value of other sanctions is likely to suffice. The factors the courts should stress, therefore, are the severity of the penalties and the frequency with which they are applied.

This analysis has been employed under the Securities Acts. In Globus v. Law Research Service, Inc., ${ }^{168}$ the Second Circuit, while conceding that punitive damages would deter violations, rejected them because they were superfluous and raised dangers of oppression. It

(1931). It should be noted that under FELA, whenever the provisions of SAA are violated, the carrier is held to strict liability and therefore might not be prompted to change conduct as a consequence of compensatory awards.

165. For example, a backpay award for unfair labor practices against an employer essentially means that the employer is paying for work that was never done, although the objective is to compensate displaced workers for lost wages. Under the Civil Rights Act [42 U.S.C. $\$ 1983$ (1970)] the jury is sometimes allowed to take the oppressiveness of the defendant's conduct into account in measuring compensatory damages. Antelope v. George, 211 F. Supp. 657, 660 (D. Idaho 1962). See note 93 supra. Similarly, recovery under section 16(b) of the 1934 Securities Act [15 U.S.C. $\$ 78 \mathrm{p}$ (b) (1970)], for profits from insider trading in securities, are calculated im such a way as to inaximize the amount recovered. Gratz v. Claughton, 187 F.2d 46, 51-52 (2d Cir. 1950), cert. denied, 341 U.S. 920 (1951).

166. The likelihood of a multiplicity of actions has been held to preclude a punitive recovery. See, e.g., Roginsky v. Richardson-Merrell, 378 F.2d 832, 840 (2d Cir. 1967) (applying New York law). Alternatively, the court may seek to create a inultiplicity of actious by offering punitive damages as an incentive to sue. This may be the best way to deter, because it would more evenly hit all wrongdoers rather than Inerely making an example of the individual before the court. It will not be necessary in each individual case, since injured parties sometimes sue merely to vindicate the justness of their cause. See Rhoads v. Horvat, 270 F. Supp. 307, 311 (D. Colo. 1967) (observing that the prime motivation of the plaintiff appeared to be a zeal to uphold his invaded civil right); $c f$. Wills v. Trans World Airlines, 200 F. Supp. 360 (S.D. Cal. 1961). However, courts should not consider deterrence on an ad hoc, case-by-case basis. See the discussion of self-help in note 138 supra.

167. This problem is particularly acute when the standard for compensatory awards is negligence, as under FELA. See note 206 infra. Under such circuinstances, violators cannot avoid compensatory awards merely by observing ordinary punitive damages standards, such as "willfulness."

168. 418 F.2d 1276, 1284-85 (2d Cir. 1969). 
stressed the possibility of extremely large compensatory liability, particularly with the possibility of class actions (equivalent for these purposes to multiple suits), and the availability of such alternative sanctions as suspension from the Securities and Exchange Commission, a fine, or a prison term. ${ }^{168}$ Other courts liave referred to some of these factors in rejecting punitive awards under the Securities Acts, presumably because a defendant risking bankruptcy or prison is not likely to be further deterred by the prospect of a punitive award. ${ }^{170}$

The threat of punitive damages may well have deterrent value under LMRA. In fact, it has been argued that punitive recoveries could have a crippling effect on unions, ${ }^{171}$ indicating that such recoveries slould be effective deterrents, particularly against large unions with substantial treasuries. Use of such awards should be limited, however, in view of the danger that they might not so much deter as destroy. ${ }^{172}$

Under the Civil Rights Act, suits are maintained against individual officers, ${ }^{173}$ wlio normally are of limited means. Courts have awarded punitive damages in these cases without considering the deterrent effect of the compensatory awards, ${ }^{174}$ probably because of the likelilood that insurance would cover them. Thus, it appears that their objective could lave been deterrence, but if their reasoning were more explicit, commentators and other courts could look into their premises more closely to analyze the probability that the objective would be achieved. This was done in another context in Wills v. Trans World Airlines,

169. Id. at 1285 .

170. See Hecht v. Harris, Upham \& Co., 283 F. Supp. 417, 445 (N.D. Cal. 1968) (concluding that punitive damages are not necessary because of the size of the compensatory recovery and the possibility of disciplinary proceedings by the National Association of Securities' Dealers).

171. See United Auto Workers v. Russell, 356 U.S. 634, 652 (1958) (Warren, C.J., dissenting) (" $[\mathrm{A}]$ very real prospect of staggering punitive damages . . . could render even those activities protected by the Federal Act too risky to undertake").

172. Thus, the court in Sidney Wanzer \& Sons, Inc. v. Milk Drivers Local 753, 249 F. Supp. 664, 671 (N.D. Ill. 1966), while upholding a punitive award under LMRA, stressed in its conclusion that the remedy should only be used as a last resort, when there is no alternative method to deter violations.

173. Monroe v. Pape, 365 U.S. 167, 187-92 (1961), held that a municipality is not a "person" within the meaning of 42 U.S.C. $\$ 1983$ (1970). The lower courts have construed Monroe as barring suits against municipalities under the Act. See, e.g., Patrum v. City of Greensburg, 419 F.2d 1300, 1302 (6th Cir. 1969), cert. denied, 397 U.S. 990 (1970); United States ex rel. Gittlemacker v. County of Philadelphia, 413 F.2d 84, 86 (3d Cir. 1969), cert. denied, 396 U.S. 1046 (1970); Wallach v. City of Pagedale, 359 F.2d 57, 59 (8th Cir. 1966). The District of Columbia Circuit has recently held, however, that suits for damages under the Act can be maintained against the munieipality. Carter v. Carlson, 447 F.2d 358, 368-70 (D.C. Cir. 1971).

174. See, e.g., Rhoads v. Horvat, 270 F. Supp. 307, 311 (D. Colo. 1967) (\$5,000 actual and $\$ 2,500$ punitive damages); Brooks v. Moss, 242 F. Supp. 531, 532 (W.D.S. Car. 1965) ( $\$ 3,500$ actual and $\$ 500$ punitive damages). 
Inc., ${ }^{175}$ where the ineffectiveness of FAA's statutory sanctions was held to justify a punitive award to deter violations. ${ }^{176}$

Other statutory sanctions cannot be expected to deter violations of FELA effectively. The only penalty provided by the Act itself is a fine for hindering a plaintiff in the exercise of his rights to recovery under the Act, ${ }^{177}$ and no cases applying the moderate penalty have been reported. ${ }^{178}$ If the SAA is also violated, its penalty provisions ${ }^{179}$ may have some deterrent effect, but the small size of the penalty ${ }^{180}$ and the rarity of its application ${ }^{181}$ should not preclude alternative use of punitive awards to deter violators.

Large coinpensatory awards are probable under FELA, however, both because injuries are likely to be serious and because railroad employees do not usually sue unless a great deal is at stake. The progressive rise in the safety of railroad employment since $1908^{182}$ may therefore indicate that the objective of promoting safer working conditions has essentially been achieved without punitive awards. It is doubtful, for example, whether Kozar's $\$ 70,000$ punitive award substantially adds to the deterrent effectiveness of the $\$ 120,000$ compensatory award. The court did not confront this question at all, although it could have cited the railroad's continued and blatant disregard of its employees' safety to demonstrate that the prospect of compensatory re-

175. 200 F. Supp. 360 (S.D. Cal. 1960).

176. Id. at 365,368 (discussing the inability of the Civil Aeronautics Board to punish violators and the inadequacy of the fine provided by the Act).

177. 45 U.S.C. $\$ 60$ (1970) [discussed in note 25 supra].

178. The penalty has been sought in only two reported cases, Greenwood v. Atchison, T. \& S.F. Ry., 129 F. Supp. 105 (S.D. Cal. 1955), where it was refused a claimant, and Dugger v. Baltimore \& O. Ry., 5 F.R.D. 334, 336 (E.D.N.Y. 1946), where plaintiff was permitted to inspect a witness' statements in the possession of the defendant, on the basis of the statute's solicitude for claimants' proof problems.

179. 45 U.S.C. $\S \S 6,13(1970)$. These sections provide that the United States Attorney may seek a penalty of $\$ 250$ in a district court for each violation of the SAA.

180. $\$ 250$ for each violation.

181. In fiscal year 1970, for example, there were only 70 suits for violations of railroad and trucking regulations combined. By comparison, there were 550 suits under the penalty provisions of the Pure Food \& Drug Act. ANNuAl RePORT of THE Director of the Administrative OfFice of the United States Courts 1970 232 (1971).

182. Although the figures on injuries are difficult to follow because they were computed on different bases in different years, it is clear that railroad work is significantly safer than it was. Chiet notes that "[a]1though railroading is still among the nation's niore hazardous employnents, its injury severity rates have declined dramatically." E. ChIET, supra note 118, at 198. The frequency of fatalities is perhaps the best index, because "injury" is now being liberally construed: of a total of 17,746 injuries reported in 1968, 4,088, or nearly a quarter, were bruises. The present fatality rate is approximately one-tenth what it was soon after the passage of FELA. Compare Dept. of Transport, Federal Ry. Admin., Accident BUlietin No. 96, Chart VII, at 6 (1927) with DePT. OF TRANSPORT, FED. Ry. ADMIN., ACcment Bulletin No. 137, Table 21, at 6 (1968). 
coveries did not cause it to improve its safety program. Furthermore, once a precedent for allowing punitive recoveries is established, the possibility that punitive damages will constitute the major portion of future FELA recoveries could of itself be an effective deterrent. The Kozar court's failure to confront the issue may therefore be simply the product of oversight rather than evidence that the court did not liave deterrence in mind in allowing the jury to award punitive damages, but the question raised by the progressive rise in safety needs to be explored in the future to justify awarding punitive damages to deter violations of FELA.

\section{IV}

\section{The Consequences of a Functional Analysis}

As the preceding part demonstrates, looking to the purpose of punitive awards under various statutes helps explain the seeimingly inconsistent treatment of the remedy. LMRA section 301 awards, for example, have been rejected for retributive, but accepted for deterrent, purposes. ${ }^{183}$ Civil Rights Act punitive awards are apparently a response to a retributive urge. ${ }^{184}$ LMRDA awards of counsel fees lave a compensatory objective, ${ }^{185}$ while punitive awards, although allegedly for deterrence, seem primcipally to serve retributive purposes. ${ }^{180}$ Punitive awards have been rejected under the Securities Acts because retribution is inappropriate in implied actions and such awards are superfluous for deterrence. ${ }^{187}$ Under FELA either a retributive ${ }^{188}$ or a deterrent $t^{189}$ theory, or both, may at times justify a pumitive award. Viewed in this light, the holdings of these courts point up some of the factors that should be considered whenever punitive damages are sought under other statutes.

Several factors argue for explicit recognition of such divergent purposes. It should enable courts to give consistent treatment to different statutes and to understand what other courts have done. It would seemingly better enable the federal courts to determine, as the Second Circuit attempted to do in Globus v. Law Research Service, Inc. ${ }^{100}$ the role of the remedy within the statutory scheme. The courts would be alertcd to the factors that should be considered in allowing or rejecting punitive recoveries: danger of self-help and importance of the rights involved for retribution, responsiveness to punitive awards and effectiveness of other

183. See text accompanying notes $128-29,157-58$ supra.

184. See text accompanying notes 132-34, 148-52 supra.

185. See text accompanying notes 113-15 supra.

186. See text accompanying notes $135,161-62$ supra.

187. See text accompanying notes $127,168-70$ supra.

188. See text accompanying notes 136-37 supra.

189. See text accompanying notes 177-81 supra.

190. 418 F.2d 1276 (2d Cir, 1969), 
sanctions for deterrence, or a need for additional compensation in order to make the statute effective. Finally, courts could mold the punitive award so that it better serves the purposes involved.

Of course, many courts might balk at explicitly recognizing their purposes, especially when the objective is retribution. Nevertheless, to the extent that punitive damages cannot be justified in terms of the issues relating to the various purposes, they sliould not be allowed, and courts should begin facing the question of when retributive awards can indeed be supported. Perhaps recognizing this need, some courts liave begun to make these distinctions when considering punitive claims under federal statutes. The Second Circuit, in rejecting punitive recoveries under section $10 \mathrm{~b}$ of the 1934 Securities Act, was careful to distinguish the factors bearing on retribution from those that were important for deterrence. ${ }^{191}$ Similarly, the court in Sidney Wanzer \& Sons, Inc. v. Milk Drivers' Local $753^{192}$ allowed a pumitive recovery under LMRA section 301 because the Third Circuit's earlier rejection of retributive punitive recoveries under the same statute did not apply to the Wanzer court's purpose. ${ }^{193}$

Courts should mold punitive awards to serve the purposes involved more effectively by altering the standards for punitive recoveries. Although atteinpting to improve the utility of punitive awards may seem to be a difficult undertaking, the federal courts liave already attempted to do so on at least one issue: the recoverability of punitive damages where there is no compensatory award. ${ }^{194}$ Consideration of the follow-

191. Green v. Wolf Corp., 406 F.2d 291, 302-03 (2d Cir. 1968), cert. denied, 395 U.S. 977 (1969).

192. 249 F. Supp. 664 (N.D. III. 1966).

193. The court said:

The core of Chief Judge Biggs' argument is that the general policy of the federal labor laws is "to supply remedies rather than punishments." The statement, while correct, is somewhat ambiguous, since courts often impose "punishments" for the explicit purpose of deterring future misconduct, a distinctly remedial notion. The distinction between remedies and punishments inust be more precisely drawn in the context of labor law.

249 F. Supp. at 670.

194. Most state courts refuse to allow them under these circumstances. W. ProsSER, supra note $125, \S 2$, at 9 . The theory behind the state rule is that punitive danages are a mere mcident to a cause of action and will not of thenselves support one. Hilbert v. Roth, 395 Pa. 270, 149 A.2d 648, 652 (1959). The federal rejection of this rule does not imply that punitive damages alone can be recovered by a plaintiff who would otherwise have no cause of action for compensatory danages; it says that all the plaintiff need show is that the defendant invaded his rights, even though the actual injury was ninimal. See Basista v. Weir, 340 F.2d 74 (3d Cir. 1965) (award of $\$ 2,500$ in punitive damages in Civil Rights Act suit upheld, although there were no compensatory damages awarded); Press Pub. Co. v. Monroe, 73 F. 196 (2d Cir. 1896) $(\$ 5,000$ in damages assessed against publisher for publishing copyrighted poem before plaintiff could deliver it to an enthusiastic throng at Chicago World's Fair; no proof of monetary danage to plaintiff). 
ing issues provides some guidelines to streamlining punitive awards to serve various purposes.

\section{A. Standard for Allowing Punitive Awards}

It is conventionally said that some aggravated conduct must be proved to support a punitive award, ${ }^{105}$ but different standards should be used to serve different purposes. Some courts have in fact suggested that they do alter the standard in light of their objective. In Sidney Wanzer, for example, the court pointed out that there was an important distinction between awards for "willful" or "outrageous" conduct, which it felt to be retributive awards, and awards for deterrence. ${ }^{196}$ Similarly, the Second Circuit upheld a punitive award against a publisher in a libel case based on neghigence, because it felt that the award would encourage greater care. ${ }^{107}$ Nevertheless, a systematic revision of the standard, designed to serve the various purposes, seems to be called for.

When the cost of litigation under a statute is likely to prevent the victims from pursuing their statutorily created remedies, punitive awards Inay be used to compensate them for such costs. ${ }^{108}$ Since there is no reason why this remedy should be available only for victims of aggravated misconduct, the standard for recovery of litigation expenses should be no inore strict than that for compensatory liability. Thus, where Congress has provided for award of counsel fees, as in the Securities Acts, ${ }^{100}$ it has left their award to the discretion of the trial court, rather than specifying what sort of conduct will invoke them. Similarly, courts awarding counsel fees under LMRDA have not focused on the offensiveness of the defendant's conduct. ${ }^{200}$

Retributive awards, on the other hand, do depend upon the nature of the defendant's conduct. If he has violated important rights, as under the Civil Rights Act, mere violation may be sufficient to justify a retributive award. The self-help rationale, however, calls for a stringent standard, because awards are proper only where the defendant's type of conduct raises dangers of retaliation. One possibility would be to return to the early common law standard, which stressed the outrageous-

195. Prosser says that the determinitive factors include malice, fraudulent or evil motive, and conscious or deliberate disregard of the rights of others. $\mathrm{He}$ says that these factors give to the defendant's conduct "the character of outrage frequently associated with crime." W. Prosser, supra note 125, § 2. McCormick contends that the sole criterion is malice. C. MCCoRMICR, supra note $26, \S 79$.

196. 249 F. Supp. at 671 n.5.

197. Reynolds v. Pegler, 223 F.2d 429, 434 (2d Cir. 1955), cert. denied, 350 U.S. 846 (1956).

198. See text accompanying notes $108-16$ supra.

199. 15 U.S.C. $\$ \S 77 \mathrm{k}$ (e) [1933 Act], 78r(a) [1934 Act] (1970).

200. See Gartner v. Soloner, 384 F.2d 348, 354-55 (3d Cir. 1967); International Bhd. of Boilermakers v. Rafferty, 348 F.2d 307, 315 (9th Cir. 1965). 
ness of the defendant's behavior. ${ }^{201}$ Such a standard would minimize the dangers of oppression by limiting the availability of retributive awards. ${ }^{202}$

The standard for deterrent awards should focus on some volitional conduct by the defendant that he and other potential defendants can change in response. Where the statute explicitly prohibits a certain type of behavior, like devious and misleading practices under the Securities Acts, further clarification does not seem necessary. ${ }^{203}$ How-

201. In Day v. Woodworth, 54 U.S. 362, 371 (1851), for example, the Court stated that punitive damages should be allowed "where the injury has been wanton and malicious, or gross and outrageous." For similar tests adopted by the Court in the 19th century, see note 27 supra.

202. Many commentators have stressed the dangers inherent in punitive awards, and retributive awards heighten these dangers. The chief objections are the absence of procedural protections analogous to those afforded the defendant in a criminal trial and the latitude given the jury in assessing damages. McCormick, for example, after pointing to these drawbacks, says "[i]t is probable that, in the framing of a nodel code of damages to-day for use in a country unhampered by legal tradition, the doctrine of exemplary danages would find no place." C. MCCormick, supra note 26, \$ 77 . See also Comment, The Imposition of Punishment by Civil Courts, 41 N.Y.U.L. REv. 1158 (1966); Comment, Criminal Safeguards and the Punitive Damages Defendant, 34 U. CHI. L. REv. 408 (1967). Under some statutes, the free rein given jury prejudices may cause great difficulty. In labor cases, for example, hot blood has been cited as a reason for denying punitive damages. Brandwen, Punitive-Exemplary Damages in Labor Relations Litigation, 29 U. CHI. L. REv. 460, 475-77 (1962); Comment, Punitive Damages in State Courts for Acts Constituting Unfair Labor Practices Under the Taft-Hartley Act, 6 U.C.L.A.L. REV. 421, 429-30 (1959). Similarly, there has been at least one case of jury incitenuent under FELA even where punitive damages were not available. Missouri-K.-T. Ry. v. Ridgway, 191 F.2d 363 (8th Cir. 1951) [discussed in note 34 supra].

The dangers of punitive awards in inappropriate situations are minimized if the judge makes an independent review of the evidence to decide whether he should instruct the jury on punitive damages. Further protections might cone from more careful review of awards by appellate courts.

203. Some of these statutes are not as clear as might be desired, however. For example, violation of the Civil Rights Act depends upon invasion of the civil rights of another under color of state law. The vagueness of the term "color of state law" and the uncertainty of determining when constitutional rights are infringed clouds the standard available to courts. Both Congress and the Supreme Court seen to feel that a clearer standard focusing on willfulness is needed. Thus, when it created a criminal sanction for violation of civil rights, Congress restricted it to willful violators. 18 U.S.C. $\S 242(1970)$. The Court has held that prosecution requires proof of specific intent. Screws v. United States, 325 U.S. 91, 101 (1945). Similarly, the criminal penalties for violation of the Securities Acts are limited to willful violations [15 U.S.C. $\$ \S 77 \mathrm{x}, 78 \mathrm{ff}$ (a) (1970)] and to knowing and willful violators of FAA [49 U.S.C. \$ 1472(a) (1970)]. By contrast, the SAA penalties do not require proof of willfulness. 45 U.S.C. $\S \S 6,13,18$ (1970).

The willfulness standard should be sufficient to give the deterred violator notice about what he inay not do without risking further punitive awards. Furthennore, deterrent awards agamst those guilty of willful violation will probably achieve Congress' objectives in enacting the statute. Under the Securities Acts, for example, the primary danger against which Congress hoped to guard coines froin intentional deceit in the market place, and, under the Civil Rights Act, froin purposeful violation of civil rights. In these cases, punitive awards under a willfulness standard would be appropriate. 
ever, where the statute merely forbids "unreasonable" or "unjust" belavior, like FAA, ${ }^{284}$ or makes compensatory hability turn on a showing of negligence, like FELA, ${ }^{205}$ something is necessary to notify the defendant how to conduct himself in the future. ${ }^{200}$ Courts could satisfy this need by reference to other statutory provisions defining acceptable conduct, ${ }^{207}$ or at least by imposing a positive good-faith standard. ${ }^{208}$

\section{B. Measurement of Damages}

Traditionally, the size of the punitive award is said to depend prin-

204. 49 U.S.C. \& 1374(b) (1970).

205. 45 U.S.C. \$ 51 (1970).

206. FELA causes particular problems in this regard. Since it makes compensatory liability turn on a showing of negligence, it offers no standard of conduct that could even arguably be adopted for punitive awards. In the first place, the prevailing view in 1908, when the statute was passed, was that mere negligence could not support a pumitive award [C. MCCoRMICK, supra note $26, \$ 79]$, so it seems completely untenable as a standard promulgated by Congress for punitive awards. Second, since even inadvertent lapses can constitute negligence, it sets a standard that sometimes cannot be observed by even the thoroughly deterred defendant. Third, such a standard is vague. The Kozar court apparently recognized that there was no value in attempting to deter all negligent conduct and set out "to deter severe violations of common law and statutory duties." 320 F. Supp. at 357. However, it should have set out what these statutory duties were. At best, the standard adopted by the court merely informs carriers that they will not be penalized for inadvertent or unavoidable failures to safeguard employees.

207. Under FELA the courts could look to the SAA requirements of such features as automatic couplers [45 U.S.C. \& 2 (1970)] and grab irons [id. \& 4] as a basic enumeration of the safety precautions carriers owe their employees. This would probably not be a wise course, however, because some of the requirements are minor or merely technical. The moderate $\$ 100$ penalty provided by Congress for SAA violations [45 U.S.C. $\$ \$ 6,13(1970)$ ] inay reflect a recognition that not all requirements are crucial to railroad safety. Indeed, although they once allowed a private right of action under the statute [Texas \& P. Ry. v. Rigsby, 241 U.S. 33, 42 (1916)], the courts no longer allow the implied right of action, while conceding that allowing such actions would add to the protections against mjury. Jacobson v. New York, N.H. \& H.R.R., 206 F.2d 153, 155-57 (1st Cir. 1953). Similarly, in Crane v. Cedar Rapids \& I.C. Ry., 395 U.S. 164 (1969), the Supreme Court demonstrated that it did not place paramount importance on enforcing the requirements of SAA by refusing to apply FELA's comparative negligence standard in favor of a worker not covered by the Act, although his injury resulted from a violation of SAA. See Note, The Safety Appliance Act and the Non-FELA Plaintiff, 58 CalIf. L. Rev. 730, 733-42 (1970). Finally, even if the courts were to impose SAA as the standard of conduct required under FELA, they would have to improvise in cases like Kozar, where no provision of SAA was violated.

208. A good faith standard seems best adapted to achieve the goal of the Kozar court-to promote safe operating conditions-because it could be focused directly on safety. The carrier could prove that it had attempted to safeguard its employees in good faith by demonstrating what safety precautions it took on their behalf. In order to protect against jury review of management decisions, the carrier should be afforded a presumption of good faith. Other carriers can protect themselves against punitive liability by carefully handling their safety programs, and the goal of promoting safe operating conditions should be promoted.

It may be argued that no explicit recognition of the good faith standard is needed 
cipally upon the character of the defendant's conduct. ${ }^{209}$ A punitive award designed to conipensate, however, clearly should be measured rather on the basis of the loss to the plaintiff, presuniably reasonable attorneys' fees. The one state court that has adopted the compensatory justification for punitive awards measures such awards on this basis. ${ }^{210}$ Retributive awards should probably be measured by the traditional formula, which was designed to guage essentially the amount needed to punish the defendant adequately. Deterrent awards should be large enough to remove any financial incentive to violate the statute, Thus, the measure for deterrence should depend upon what the defendant hoped to gain by his misconduct, and should possibly be increased to provide for the improbability of punishment.

\section{Appellate Review}

Appellate review of punitive awards is traditionally said to be more constricted than that of compensatory awards because the measurement of punitive damages is peculiarly within the competence of the jury. ${ }^{211}$ This position seems untenable in light of the multiple objections of commentators to jury competence. ${ }^{212}$ It may be justified where the purpose of the award is retributive, because the jury should be better able to assess the amount needed to satisfy the community's desire to punish the wrongdoer. ${ }^{213}$ Where the objective of the award is compensation, how-

to make the Kozar award effective, because carriers will take it to mean that they must prove they conscientiously repair tools and otherwise safeguard employees. While this is probably true, it is preferable to clarify what is expected so that all carriers can be sure of it and no courts will be confused about how to handle deterrent awards under FELA.

209. The Supreme Court, in the first case in which it upheld a punitive award, said that "the damages assessed depend on the circumstances showing the degree of moral turpitude or atrocity of the defendant's conduct." Day v. Woodworth, 54 U.S. 362,371 (1851). Since then, the factors to be considered in making a punitive award have been broadened to include the wealth of the defendant, the amount of injury done to the plaintiff, and the wantonness of the defendant's conduct. RESTATEMENT of ToRTs $\S 908(2)$ (1939); C. MCCoRMICK, supra note 26, \$ 85, at 297-98.

210. Doroszka v. Lavine, 111 Conn. $575,578,150$ A. 692, 692-93 (1930).

211. Restatement OF TORTS $\$$ 908(2) (1939).

212. The central concern of the commentators worried about jury competence has been the latitude given the jury in assessing the amount of punitive awards. This was one of McCormick's principal objections. C. McCormick, supra note $26, \S 85$. These problems are exacerbated by the absence of the protections for the defendant that are afforded him in criminal trials. See Note, Criminal Safeguards and the Punitive Damages Defendant, 34 U. CHr. L. REv. 408, 426-29 (1967). Further difficulties result from appeals to prejudice, which may be of special importance uuder soine statutes. See note 202 supra.

213. Careful appellate review may still be necessary when the purpose is to vindicate what the court feels are fundamental rights. Since the courts decide what rights deserve vindication through this means, they should also take a more active role in determining how $m u c h$ vindication is required. Note that an appellate court can reverse when it feels an award is too low as well as when it is too high. 
ever, there is no reason why the court is not as competent to review the award as it is to review an ordinary compensatory award. There is even less reason to expect the jury to be competent in measuring deterrent awards. In criminal trials, for example, the judge determines the amount of the punishment. Therefore, deterrent punitive awards should probably be subject to closer appellate scrutiny than ordinary compensatory ones.

\section{CONCLUSION}

The Kozar award may have been designed for retributive ${ }^{214}$ or deterrent $^{215}$ purposes, or both. The court's opinion implies that it entertained both goals. Although it did not expressly separate these objectives, it should have confronted the issues crucial to each: dangers of self-help for retribution ${ }^{216}$ and effectiveness of punitive awards for deterrence. $^{217}$ Until punitive awards under FELA and other statutes are expressly made dependent on the factors that are relevant to the various purposes, uncertainty will continue to pervade the area. Courts should abandon rebiance on factors like common law availability of the remedy and inferred congressional intent, and rely instead on the criteria suggested in this Comment.

If courts do explicitly distinguish their purposes, as some have, ${ }^{218}$ they break with precedent and invite other modifications of traditional rules. ${ }^{219}$ They also make it more probable that implied remedies, streamlined to achieve their purposes, will take their place beside implied causes of action as important imstruments for achieving congressional goals.

Richard Marcus

214. See text accompanying note 137 supra.

215. See text accompanying note 163 supra.

216. See text accompanying notes 136-37 supra.

217. See text following note 182 supra.

218. See text accompanying notes 191-93 supra.

219. See text accompanying notes 195-213 supra. 